\title{
PRECIPITATION, EVAPORATION AND ENERGY EXCHANGE AT THE SURFACE OF THE SOUTHEAST ASIAN WATERS
}

\author{
by \\ KLAUS WYRTKI
}

The full understanding of the distribution of the surface temperature and salinity requires the knowledge of the heat and water balance at the surface of the ocean as well as of the circulation. For southeast Asian waters the monthly averages of the climatological factors determining the heat and water balance are calculated and presented in the following for 15 regions. The positions of the 15 regions are given in fig. 1 , the values are averages of 8 to $121^{\circ}$ squares situated about in the centre of the region, to avoid disturbances by effects from the land.

The precipitation over the different regions has been taken from representations given by WYRTKI (1956) showing the annual variation of rainfall over the sea by means of an evaluation of the observations of coastal and island stations in the Indonesian Archipelago. For the regions outside the archipelago the same method has been applied for the determination of the annual variation of the rainfall, table 7 .

The evaporation of the different regions has been calculated by means of the formula given by SVERDRUP (1946). In this formula the evaporation is proportional to the wind velocity $\mathrm{v}$ and to the vapour pressure difference between sea and air $\mathrm{e}_{\mathrm{w}}-\mathrm{e}_{\mathrm{a}}$,

$$
\mathrm{E}=\mathrm{k}\left(\mathrm{e}_{\mathrm{w}}-\mathrm{e}_{\mathrm{a}}\right) \mathrm{v} \text {. }
$$

This formula is theoretically founded and has been used successfully for the calculation of the evaporation, so that not it, but the used observation material needs critical consideration. Besides the wind velocity and the water and air temperatures, the relative humidity enters the formula, which is difficult to determine, but plays on important role in the calculation. If $E_{a}$ is the vapour pressure of the saturated air, and $q$ the relative humidity, the evaporation is given by

$$
E-k\left(e_{w}-q E_{a}\right) v \text { or }
$$

written in an other way

$$
E=k\left(e_{w}-E_{a}+(1-q) E_{a}\right) v
$$




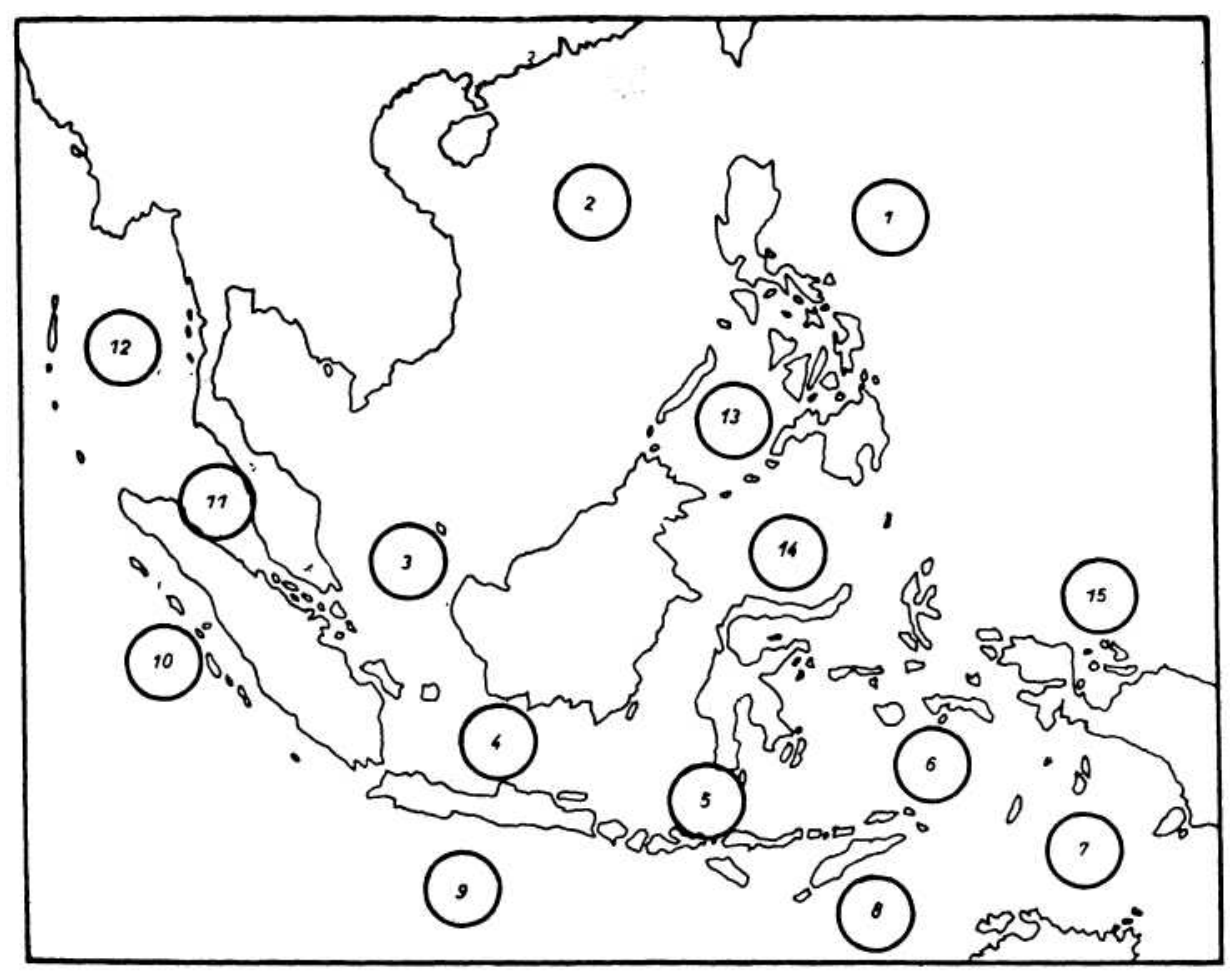

Fig. 1. Position of the regions for which the data of the water and energy balance have been computed. Numbers refer to those used in table 1 to 14 . 
Because the water and air temperatures over the sea are nearly equal, the difference $e_{w}-E_{a}$ practically vanishes, and the evaporation depends effectively on the factor $(1-q)$, which is the deficit of the saturation. But this value varies considerably in the tropical monsoon climates because the humidity is high, between 90 and 70\%. This means, that the factor $(1-\mathrm{q})$ varies as 1 to 3 .

The factor $\mathrm{k}$ in the evaporation formula, which can be derived from the boundary layer theory, has to be considered carefully, because the formula is valid only for simultaneous values of wind velocity and vapour pressure differences. But because normally the product of averages differs from the average of single products, this theoretical calculation of $\mathrm{k}$ is only of limited value. This means, that the coefficient has to be determined empirically. If the wind velocity $\mathrm{v}$ is measured in $\mathrm{m} / \mathrm{sec}$, the vapour pressure in millibars and the evaporation in $\mathrm{mm} /$ day, the following values of $\mathrm{k}$ have been used by the named authors:

$\begin{array}{lll}\text { SVERDRUP } & 1946 & 0.103 \\ \text { BROGMUS } & 1952 & 0.104 \\ \text { ALBRECHT } & 1951 & 0.092 \\ \text { JACOBS } & 1951 & 0.143\end{array}$

For these calculations $\mathrm{k}=0,100$ has been taken, giving slightly smaller values than SVERDRUP, an effect which could perhaps be balanced because for the transformation of the wind velocity from Beaufort scale to $\mathrm{m} / \mathrm{sec}$ the maritime convertion scale has been used, giving slightly higher values than the most other scales in use.

The temperature of the water and of the air has been taken from the Dutch climatological atlasses $(1936,1949)$. This material is not only very comprehensive, but is almost throughout based upon simultaneous observations of the water and the air temperature, which is of importance for our investigations. Therefore the values of the World Atlas of Sea Surface Temperatures (1950) have not been used. A comparison between this atlas and the Dutch atlasses shows deviations up to $1,0{ }^{\circ} \mathrm{C}$ in certain months and regions, of which the frequency distribution is shown in fig. $2 \mathrm{a}$. On the average the temperatures of the US atlas are $0,10^{\circ} \mathrm{C}$ higher than those of the Dutch atlasses. The monthly values of the temperatures of the sea water and of the air are given in table 1 and 2 .

The difference between water and air temperature varies in the different months and regions between $0,8^{\circ}$ and $-0,2^{\circ} \mathrm{C}$ and has an average of $0,31{ }^{\circ} \mathrm{C}$, fig. $2 \mathrm{~b}$. Negative values appear only over the regions of upwelling off the northwest coast of Australia during the southeast mon- 


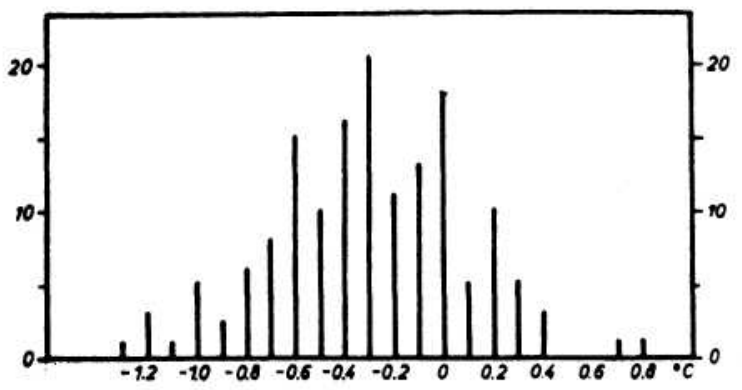

Fig. 2a.

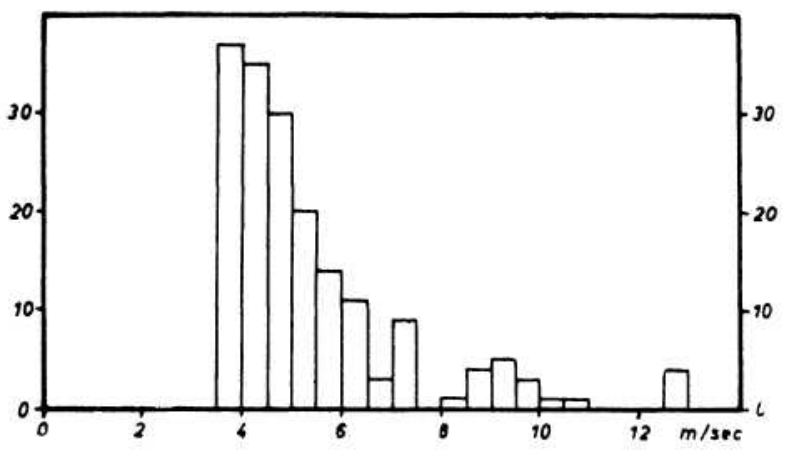

FIG. 2b.

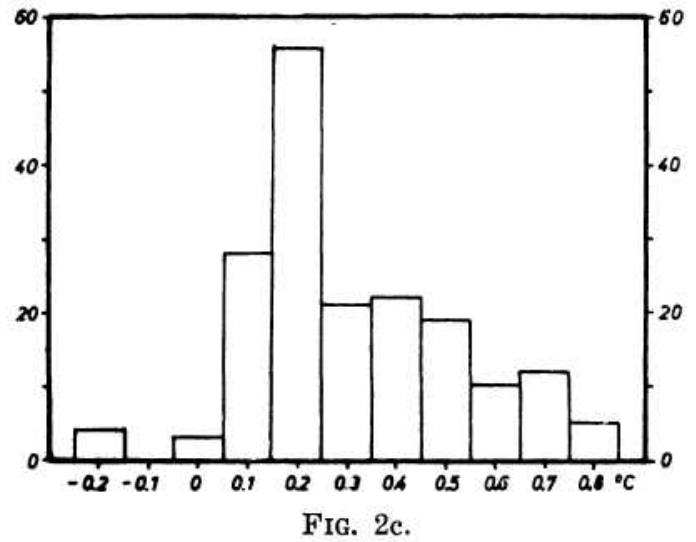

Fig. 2a. Frequency of the average monthly difference of the sea surface temperature obtained from the Dutch climatological atlasses and from the World Atlas of Sea Surface Temperatures.

Fig. 2b. Frequency of the average monthly wind velocities in the 15 regions.

Fig. 2c. Frequency of the average monthly temperature difference between sea and air. 
soon. The results of the Snellius Expedition, VISSER (1936), on the other hand have shown, that the temperature of the water is on the average $0,7^{\circ} \mathrm{C}$ higher than that of the air, indicating a falsification of the observations of the merchant ships. Therefore these values can not be used to calculate the exchange of sensible heat between sea and atmosphere, while the values of the temperature may be considered to be representative for normal climatological conditions. The annual variation of the water and the air temperature are presented in figs. 3-9.

The relative humidity is necessary for the determination of the vapour pressure of the air, but its determination makes rather big difficulties, and effects considerably the results. The psychometric difference given in the Atlas of Climatic Charts of the Oceans (1938) can not be used in this case, because only values at Greenwich noon are used, corresponding to 18 to 21 hours local time. In the beginning of the night the humidity is often high because of rainfall in the afternoon. Therefore the direct climatological observations of the relative humidity at coastal and island stations have widely been used. The values of the weather side and leeside stations have been compared and it was accepted, that the weather side stations give the real values over the sea; they are given in table 3 . The obtained vapour pressures of the air have been compared with those given by ALBRECHT (1951) and correspond with them with the exception of some explainable cases. Generally the variation of the humidity can be said to run parallel to that of the rainfall, allowing for the selection of the suitable values in some doubtful cases.

The wind velocity has been determined in two independent ways. First the ships' observations collected at the Institute of Marine Research in Djakarta were examined statistically, but the cover only a period of 7 years. Second, the Atlas of Climatic Charts of the Oceans has been used. It gives charts of the wind velocity only for every season, but besides that charts of the frequency of the wind velocity for every month. The evaluation of these data was favoured by the fact that in this region the average wind velocity is about 3 Beaufort, and the atlas gives information about the percentage of winds above and below 3 Beaufort. By means of a statistic of the wind velocities in this region, it could be determined, which average wind velocities belong to a certain frequency in the atlas. These results correspond very close to the direct ships' observations, so that they were used without further critical consideration. The transformation into $\mathrm{m} / \mathrm{sec}$ was made using the maritime conversion scale, which gives relatively high values. The monthly averages of the wind velocity are 
given in table 5, their frequency is shown in fig. 2c and indicates the high percetage of weak winds.

By means of the temperature of the water and of the air and of the relative humidity the vapour pressure difference between sea and air could be calculated, table 4. Multiplication of these values with the wind velocity v, the factor $\mathrm{k}$ and the number of days in the different months gives the evaporation, table 6 . The annual variations of all these factors are presented in figs. 3-9, and the annual variation of the rainfall, table 7 , of the difference between rainfall and evaporation, table 8 , and of the surface salinity have been added.

The energy exchange at the surface of the ocean satisfies the equation

$$
\mathrm{Q}_{\mathrm{r}}-\mathrm{r} \mathrm{Q}_{\mathrm{r}}-\mathrm{Q}_{\mathrm{b}}-\mathrm{Q}_{\mathrm{e}}+\mathrm{Q}_{\mathrm{conv}}+\mathrm{Q}_{\mathrm{adv}}+\mathrm{Q}_{\mathrm{h}}
$$

and the different symbols have the following meaning:

$\mathrm{Q}_{\mathrm{r}} \quad$ total radiation from sun and sky.

$r \quad$ percentage of reflected radiation.

$\mathrm{Q}_{\mathrm{b}} \quad$ back radiation from the sea surface.

$\mathrm{Q}_{\mathrm{e}} \quad$ energy used for evaporation.

$\mathrm{Q}_{\text {con }}$ convection of sensible heat to the atmosphere.

$\mathrm{Q}_{\text {adv }} \quad$ advection of heat by currents and mixing.

$\mathrm{Q}_{\mathrm{h}} \quad$ heat used for heating of the water, cooling negative.

The total incoming radiation is easy to calculate from the values given by KIMBALL (1928), if the average cloudiness is known. Information on the cloudiness have been taken from the Atlas of Climatic Charts of the Oceans (1938) and from SCHOTT (1935), from which the annual variation of the cloudiness has been interpolated, table 9 . The values of the incoming radiation at clear sky $Q_{0}$ according to KIMBALL have been interpolated for the average latitude of the region and reduced according to the cloudiness $\mathrm{C}$ with the formula

$$
\left.\mathrm{Q}_{\mathrm{r}},=\mathrm{Q}_{\mathrm{o}} \mathrm{d}-0,071 \mathrm{c}\right)
$$

The percentage of reflected radiation has been considered to be $3 \%$. The back radiation is determined by means of the diagram given by SVERDRUP (1946) as a function of sea surface temperature and relative humidity. It is reduced according to the cloudiness $\mathrm{C}$ with the formula

$$
\mathrm{Q}_{\mathrm{b}}=\mathrm{Q}_{\mathrm{bo}}(1-0,083 \mathrm{C})
$$

From these three values the total effective radiation at the sea surface $Q_{\text {eff }}$ is calculated by

$$
\mathrm{Q}_{\mathrm{eff}}=\mathrm{Q}_{\mathrm{r}}-\mathrm{r} \mathrm{Q}_{\mathrm{r}}-\mathrm{Q}_{\mathrm{b}}
$$


These values are given in tables 10, 11 and 12. They show in nearly all regions two maxima during the course of the year, which is due to the position between both tropics. The influence of the cloudiness modifies this distribution only a little, because in large areas the cloudiness varies only between 50 and $65 \%$. Only during the southeast monsoon the cloudiness decreases in its range to below $40 \%$.

Opposite to this effective radiation are the energies used for evaporation, heating or cooling, for the exchange with the atmosphere and for advective processes. In tropical regions the evaporation surely plays the domineering role, and its energy consum is calculated by multiplying the evaporation with the heat of vaporisation $\left(582 \mathrm{cal} / \mathrm{g}\right.$ at $\left.28^{\circ} \mathrm{C}\right)$, table 13 . The exchange of sensible heat amounts in the tropics to about 5 to $10 \%$ of the heat used for evaporation, and temporarily it may become negative. Its calculation is difficult because of the small temperature difference between sea and air, which is not known exactly enough. Therefore its calculation has been omitted.

For a representation of the energy balance of the different regions, figs. 4-9, the total effective radiation $\mathrm{Q}_{\text {eff }}$ is shown and the difference $\mathrm{Q}_{\mathrm{eff}}-\mathrm{Q}_{\mathrm{e}}$, being the heat available for heating and cooling of the sea and the atmosphere as well as for advective processes, table 14. A comparison between the difference $Q_{\text {eff }}-Q_{e}$ and the annual variation of the water temperature shows in most of the regions a strong correlation between the available heat and the increase or decrease of the temperature. Numerically a heat surplus of $100 \mathrm{cal} / \mathrm{cm}^{2} /$ day heats during one month a water layer of 30 meters by $1{ }^{\circ} \mathrm{C}$. But for an exact comparison of both values a complete knowledge of the thermal structure of the water masses would be necessary, because advective processes might play an important role. To gain an impression of their magnitude, a short estimation might be valuable. In the discontinuity layer of the Atlantic Ocean MONTGOMERY (1939) calculates the vertical eddy diffusivity at about 0,4 gem/sec. With this value and with a temperature gradient of $10{ }^{\circ} \mathrm{C}$ within 100 meters depth a heat transport of $36 \mathrm{cal} / \mathrm{cm}^{2} /$ day results. This rather high amount of heat transport into the depth might be an essential factor in the energy balance, but it is relatively difficult to obtain exact values. The effect of this vertical heat transport on the other hand is easy to recognize in the continuous increase of the temperature in the core layer of the intemediate water, which is situated below the discontinuity layer. The horizontal heat transports on the other hand seem to be less important because of the small horizontal temperature gradients in this region, 


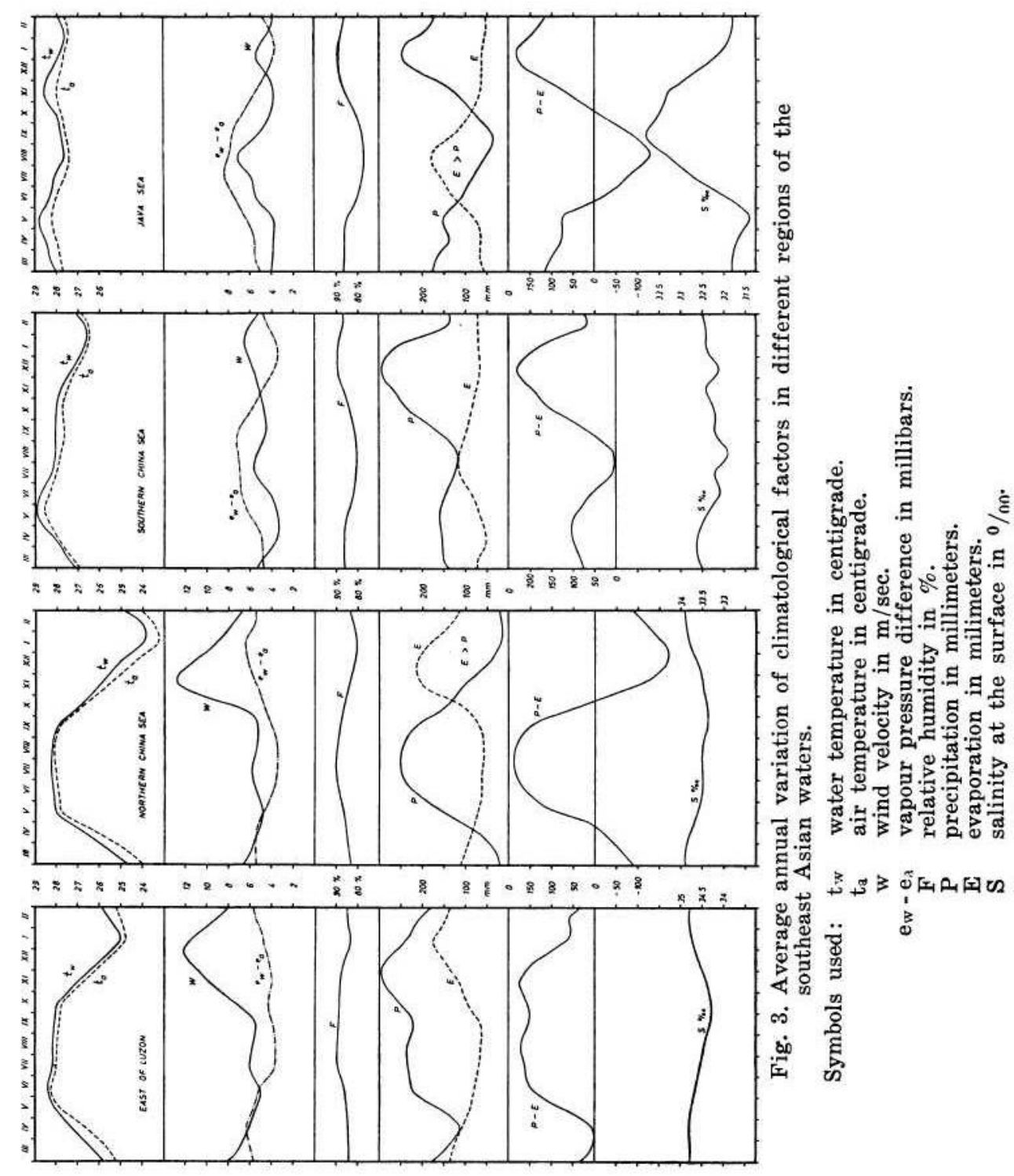



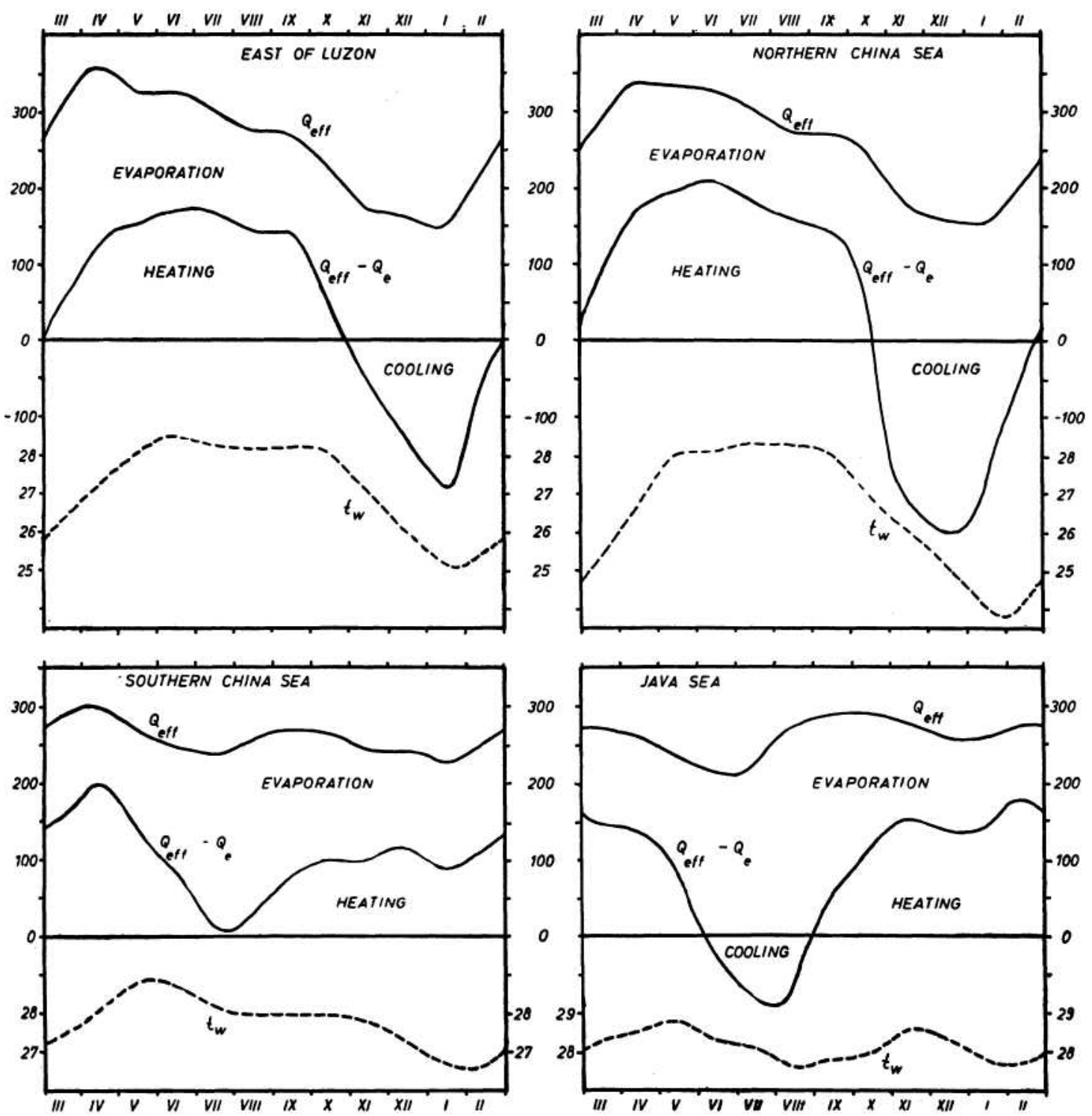

Fig. 4. Average annual variation of climatological factors in different regions of the southeast Asian waters.

Symbols used: $Q_{\text {eff }}$ total effective radiation at the sea surface.

$\mathrm{Q}_{\mathrm{e}} \quad$ energy used for evaporation,

$t_{w} \quad$ water temperature in centigrade. 
only in special cases they will have some influence and one of them is discussed in connection with the Malacca Strait.

Although the character of this investigation of the energy balance of the southeast Asian waters might be preliminary, so it gives an impression of the combined action of the different factors. This may be discussed in some detail, when dealing with the conditions in the different regions in the following.

Over the northern parts of the China Sea there is a rainy and a dry season, and in the latter the evaporation essentially exeeds the rainfall. The high evaporation during the months from November to March is chiefly a result of the strong winds during the northeast monsoon, but is intensified by the lower relative humidity in this season. The maximum of the relative humidity occurs in the rainy season. With the beginning of the northeast monsoon the water temperature decreases because more energy is used for evaporation than available from the radiation. The variation of the surface salinity corresponds to that of the difference between evaporation and precipitation.

The region east of Luzon, which is about in the same latitude and has similar wind conditions lacks the dry season, because also during the northeast monsoon wet air masses are domineering and lead to high rainfall throughout the year. These exceed the evaporation in every month. Also in this region during the northeast monsoon the temperature falls by $4^{\circ} \mathrm{C}$.

The energy balance of both regions shows a similar pattern. The maximal radiation is available in the months from April to July, that is just the season with weak evaporation. During the months November to February on the other hand the energy consumption of the evaporation is bigger than the effective radiation, causing a cooling of the water. The total energy used for evaporation during these four months in the northern China Sea amounts to $21000 \mathrm{cal} / \mathrm{cm}^{2}$ which is sufficient to cool a layer of 50 meters by $4^{\circ} \mathrm{C}$. But the cooled layer is about 70 meters thick, which follows, that advective processes must be effective. This is in agreement with the advance of cool water masses through the Formosa Strait.

Over the southern parts of the China Sea a strong rainy season is developed from October to January, but a real dry season is lacking, so that the rainfall exceeds the evaporation during the whole year. Since winds are always weak, the evaporation is low, only in the months July/August, when the humidity is low, it exceeds $100 \mathrm{~mm} / \mathrm{month}$. The energy balance shows the effective radiation exceeding the energy needed 
for evaporation in every month. From this results a continious warming of the water, even if a part of the energy is given off to the atmosphere. Because in this region a heat transfer to the depth is possible only in a limited scale, horizontal transports must carry the surplus of heat out , of the region. In the months from November to February a cooling of $1^{\circ}$ is noted, which must be caused by the advancing of cooler water masses from the north. The warmed water masses move with the north monsoon into the Java Sea. Afterwards a warming takes place coinciding with the maximum of the incoming radiation. The stronger evaporation in July/August causes a weak decrease of the temperature because besides the evaporation sensible heat is given off to the dryer airmasses of the southeast monsoon.

Over the Java Sea again a rainy and dry season is found. In the dry season during the southeast monsoon the evaporation exceeds the rainfall. High wind velocities and a low relative humidity cause an evaporation of more than $100 \mathrm{~mm} / \mathrm{month}$. During the months from June to August the energy necessary for the evaporation exceeds the avialable radiation and a cooling takes place. The deficit amounts to $5700 \mathrm{cal} / \mathrm{cm}^{2}$ within these three months, corresponding to a cooling of a 40 meters deep layer by $1.4^{\circ} \mathrm{C}$, which is in accordance with the observations. The cooling in December and January is not in accordance with the energy balance, but during both these months the north monsoon is most strongly developed and brings with relatively strong winds cool and rainy air masses into this region. Perhaps the evaporation might be underestimated in these months. Remarkable in this connection is the variation of the temperature in the Java Sea, showing a semiannual period well developed. The maxima occur in May and November, just during the kentering of the monsoons if the wind velocities are lowest. The minima of the temperature occur together with the full development of both monsoons in August and February.

In the Flores Sea a, similar variation of the temperature exists, but the cooling during the southeast monsoon is stronger. The evaporation exceeds during four months the rainfall, and is caused chiefly by the small relative humidity. The energy balance shows from June to August an excess of the energy for the evaporation over the effective radiation. This amounts to $7500 \mathrm{cal} / \mathrm{cm}^{2}$ and is sufficient to cool a homogeneous layer 40 meters thick by $2^{\circ} \mathrm{C}$, which is in agreement with the observations. From September the temperature rises again, the maximum is reached in December. At the time of the full development of the west monsoon over the Flores Sea in January the temperature drops again, in spite of 


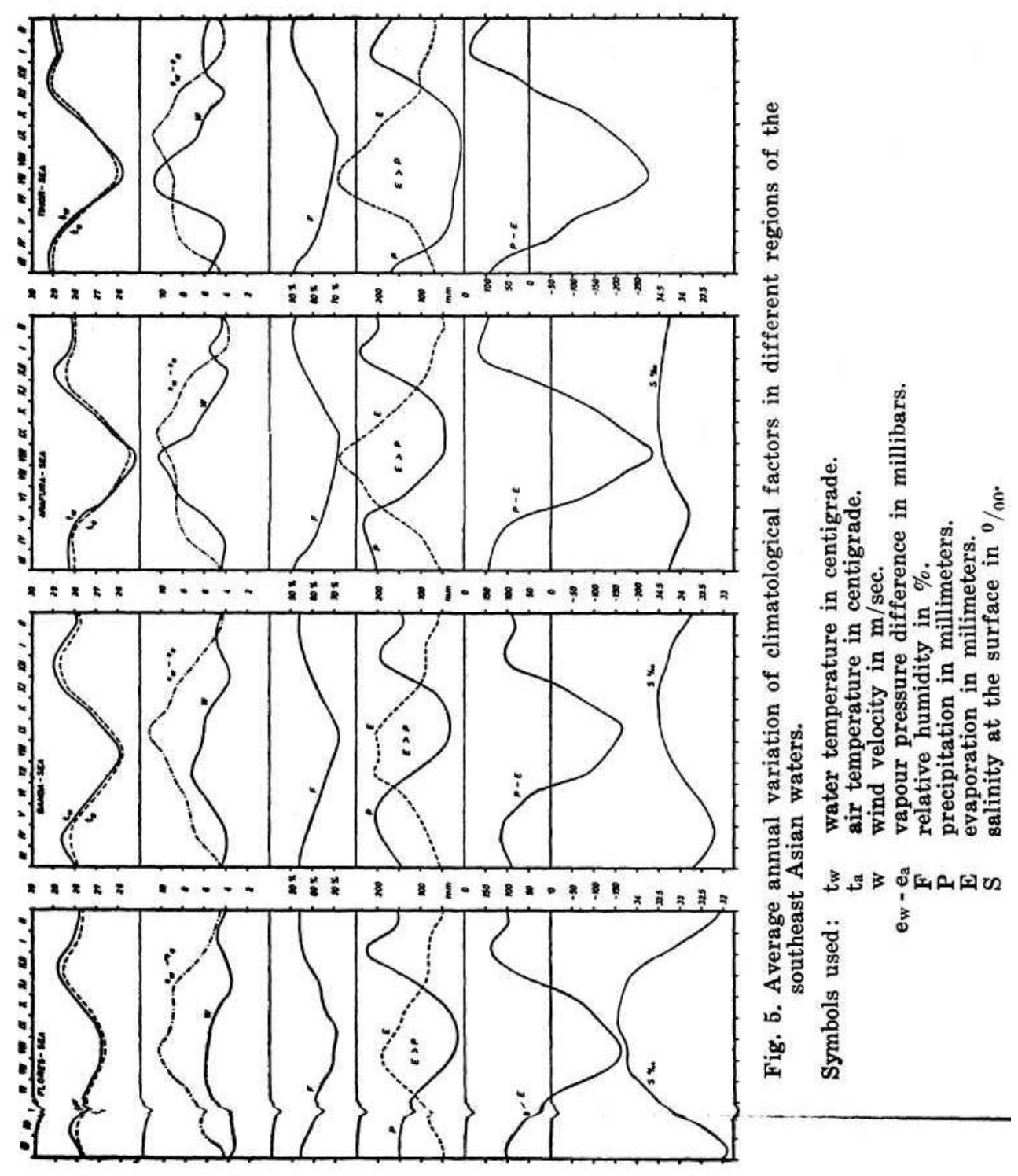



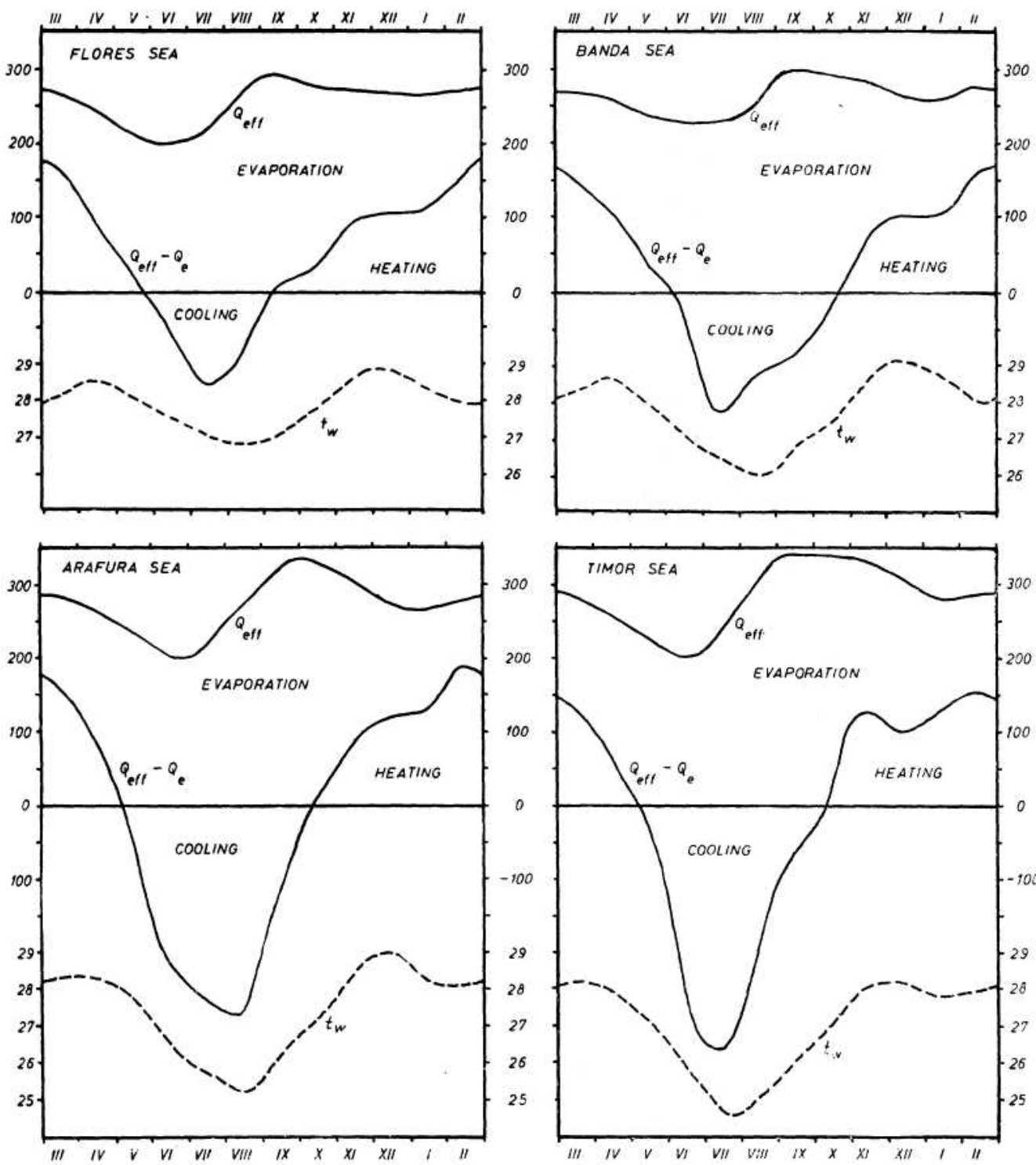

Fig. 6. Average annual variation of climatological factors in different regions of the southeast Asian waters.

Symbols used: $Q_{\text {eff }}$ total effective radiation at the sea surface.

$\mathrm{Q}_{\mathrm{e}}$ energy used for evaporation,

$\mathrm{t}_{\mathrm{w}} \quad$ water temperature in centigrade. 
the positive energy balance during this time. This cooling effect in the Flores Sea might be interpreted as an vertical extension of the homogeneous layer due to the increase of the wind velocity during the west monsoon. If the homogeneous layer is deepened by mixing, the average temperature must decrease. But to show this requires a detailed knowledge of the variation of the thermal structure of the water masses during the year, which can not yet be given.

In the Banda Sea the conditions are similar to those in the Flores Sea, but the excess of evaporation and the cooling during the southeast monsoon are stronger. The maxima of the surface temperatures occur in April and December at the time of the kentering of the monsoons.

The Arafura Sea and the Timor Sea are closest to the region of origin of the southeast monsoon, and are most strongly influenced by its dry cool air masses. The wind velocities over these open seas are high and the humidity of the offshore winds is low, causing extremely high values of the evaporation. But the Atlas of Climatic Charts of the Oceans shows in this region during the whole year depressions of the wet bulb of only 0,5 to $1,0^{\circ} \mathrm{C}$, which certainly must be an error during the southeast monsoon season. In the Arafura Sea the evaporation exceeds the rainfall during five months; in the Timor Sea even during seven months. Maximal values of the evaporation of nearly $300 \mathrm{~mm} / \mathrm{month}$ are reached as a combined effect of strong winds and dry air. During July and August the water temperature is lower than that of the air, which might be due to upwelling processes. The rainy season in the Timor Sea is only short and takes place at the time, when the equatorial trough lies over this region. The Arafura Sea has two rainfall maxima, occuring when the equatorial trough passes the region, but the secondary minimum is only weakly developed.

The energy balance shows two maxima of the radiation, which is an effect of the position inside the tropics. The curves of the effective radiation are strongly modified by the cloudiness, which is very small during the southeast monsoon and above 60\% during the rainy season. In the months from May to September, when the energy needed for evaporation exceeds the effective radiation, a strong cooling of the water takes place. The required energy during this time is about $27000 \mathrm{cal} / \mathrm{cm}^{2}$, sufficient to cool a 90 meters deep layer by $3^{\circ} \mathrm{C}$.

The region south of Java shows qualitatively the same conditions as the other regions in the southeast of the Archipelago. From May to October it is under the influence of the southeast monsoon, from December to February the equatorial trough lies over the region and brings the 


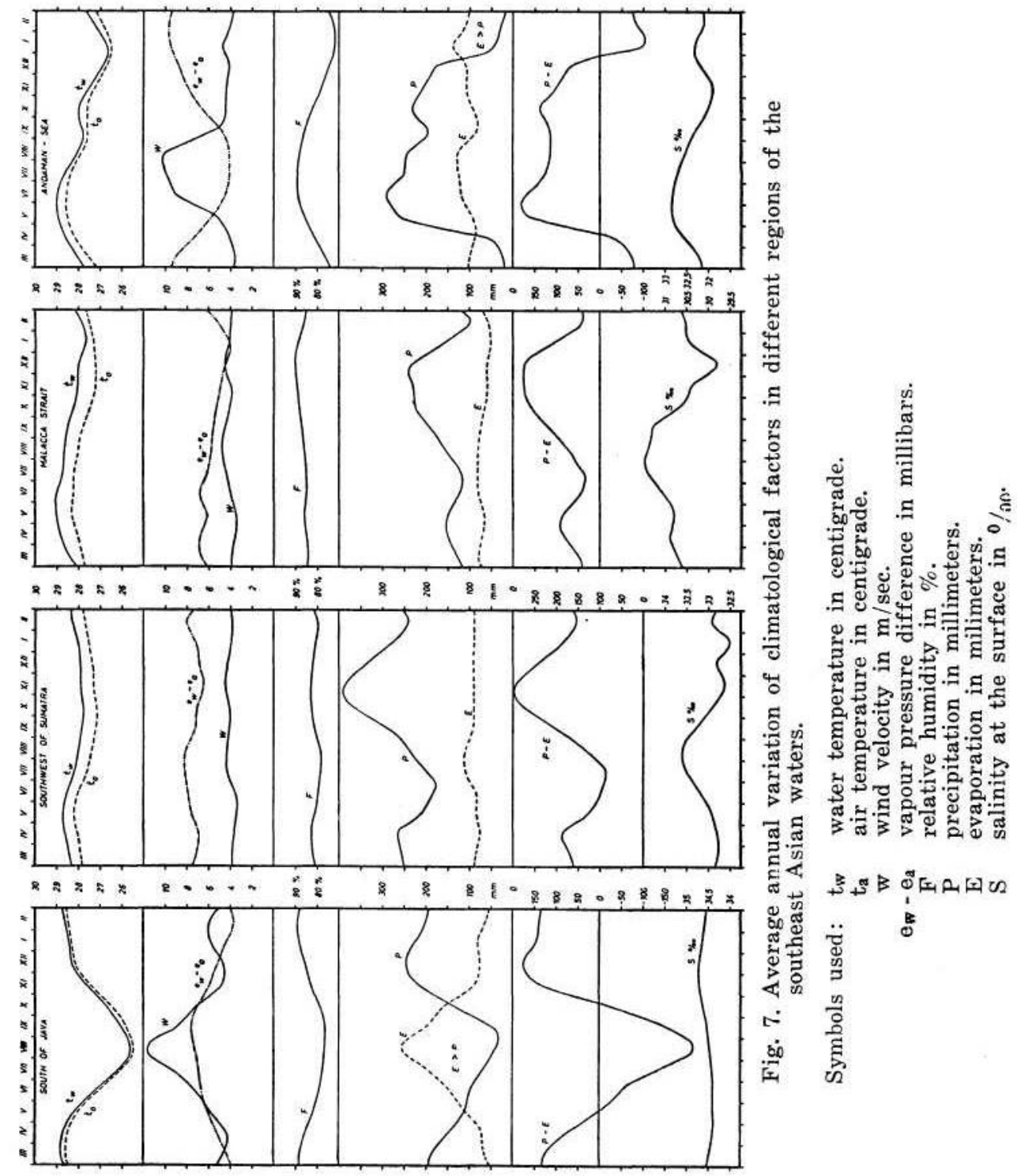



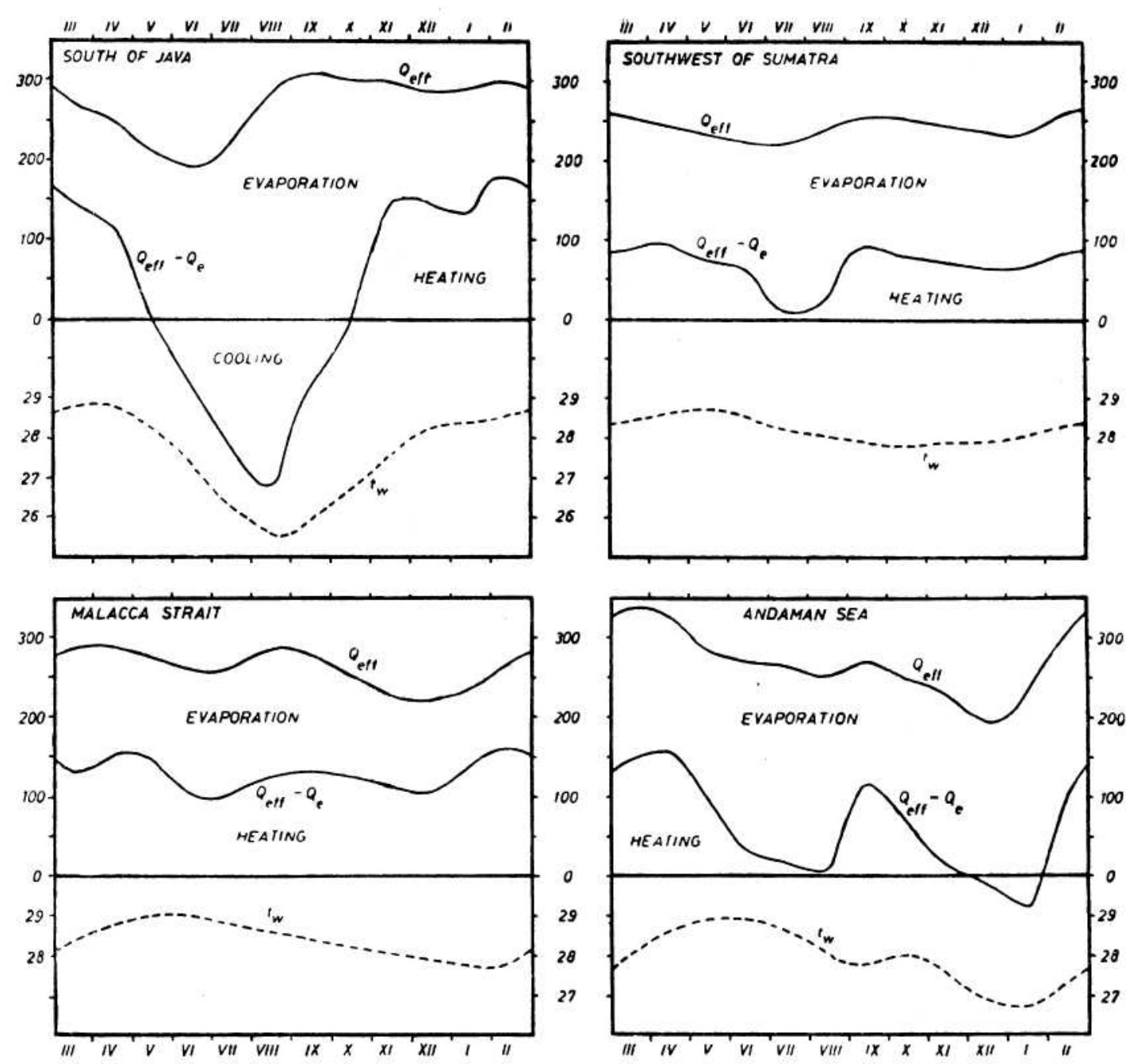

Fig. 8. Average annual variation of climatological factors in different regions of the southeast Asian waters.

Symbols used: $Q_{\text {eff }}$ total effective radiation at the sea surface.

$\mathrm{Q}_{\mathrm{e}} \quad$ energy used for evaporation.

$\mathrm{t}_{\mathrm{w}} \quad$ water temperature in centigrade. 
rainy season. The highly balanced annual variation of the meteorological conditions causes an also smooth run of the surface temperature and salinity in this region far from influences of the land. Both effects agree numerically with the calculated values.

The region southwest of Sumatra has with $3000 \mathrm{~mm} /$ year an extremely high rainfall, which drops in no month below $180 \mathrm{~mm}$, meaning, that a real dry season does not exist. The two periods of especially strong rainfall occur when the equatorial trough passes the region. During these two times also the maxima of the relative humidity are found. The curves of the wind velocity and of the vapour pressure difference show only small variations, and cause a relatively constant evaporation of about $90 \mathrm{~mm} / \mathrm{month}$. An exception is found in July and August, when the southeast monsoon has some influence and the evaporation reaches $110 \mathrm{~mm}$.

Also the energy balance is rather equalized, and gives during the whole year a contribution to a heating of the water. This heat is given off partly to the atmosphere, which follows from the relatively high difference between sea and air temperature. Another part might be transferred by advection horizontally and vertically. The annual variation of the temperature is less than $1^{\circ} \mathrm{C}$, an indication for the stability of the conditions.

In the Malacca Strait the conditions are rather similar. Also there two rainy seasons are found without a real dry season between them. The relative humidity is extremely high, and because of the weak winds the evaporation is small. Only a part of the effective radiation will be used for evaporation and so a continious heating of the water would occur, if advective processes would not transfer the exess heat. It might be useful to estimate the numerical value of this energy transfer. At a horizontal temperature gradient $\mathrm{dt} / \mathrm{dx}$ of $1^{\circ} \mathrm{C}$ in $2000 \mathrm{~km}$ and a velocity of the current of $\mathrm{v}=25 \mathrm{~cm} / \mathrm{sec}$ the heat Q transported in a layer of a depth $\mathrm{D}$ $=40$ meters will be $\mathrm{Q}=\mathrm{c} \mathrm{v} \mathrm{D} \mathrm{dt} / \mathrm{dx}$, and numerically $44 \mathrm{cal} / \mathrm{cm}^{2} / \mathrm{day}$. Such an amount already has to be considered in the energy balance. Also the difference between sea and air temperatures reaches relatively high values in the Malacca Strait, indicating a large transfer of sensible heat to the atmosphere.

Over the Andaman Sea the regime of the Indian monsoon is already met. It brings from May to November a continious strong rainy season, in the other month a nearly rainless dry season. The evaporation has two weak maxima, one during the dry season, caused by the small relative humidity, the other during the rainy season, when the wind is strongest. Because both factors are counteracting, the variation of the evaporation 


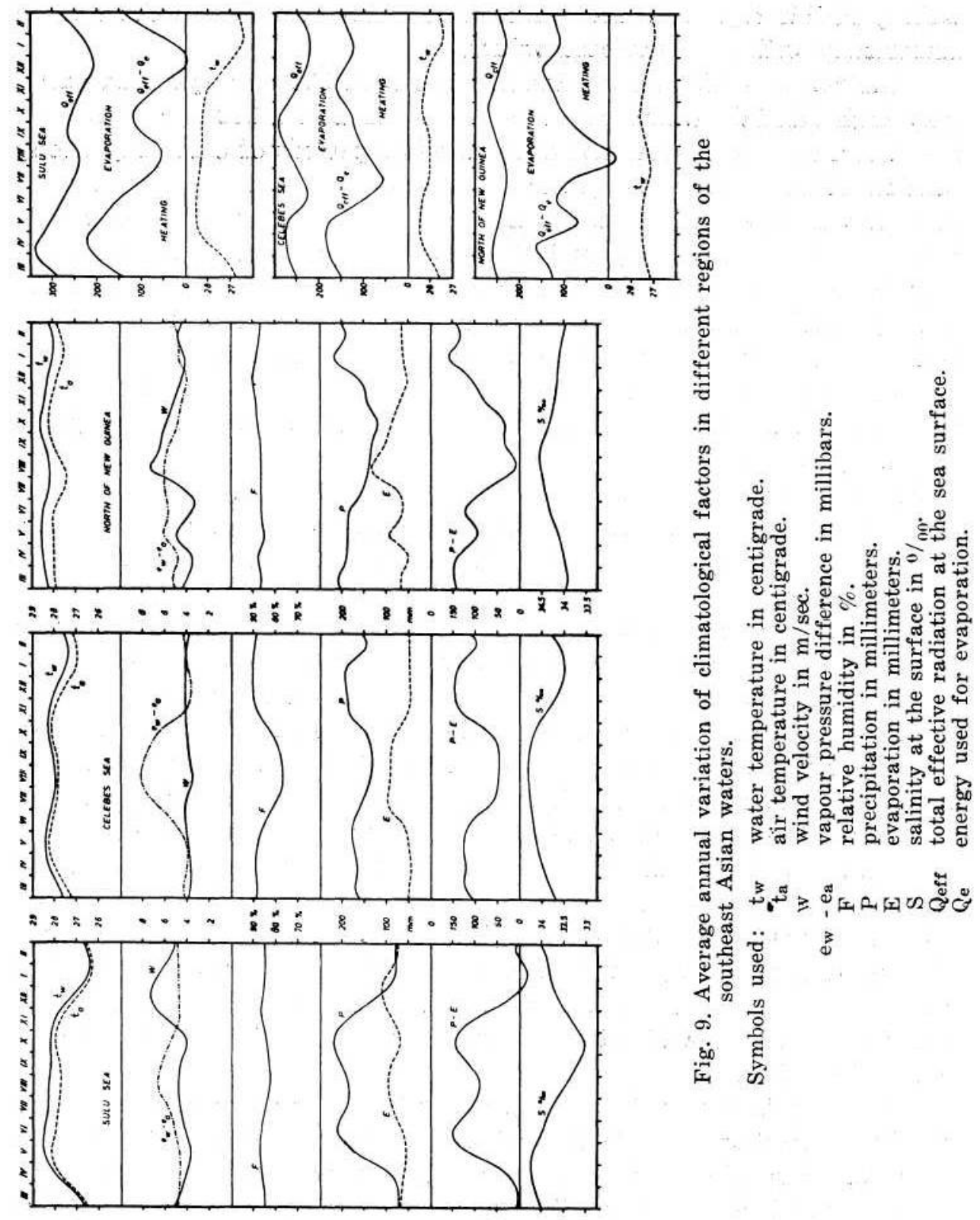


is only small. In spite of that it exeeds the rainfall considerably during the dry season. The energy balance indicates the effective radiation normally exeeding the energy used for evaporation. Also a small transfer to the atmosphere must take place. The curve of the surface temperature corresponds to the available energy, during the periods of strongest energy surplus a heating takes place, during the periods of maximal evaporation the cooling occurs.

Over the Sulu Sea an extended rainy season occurs from May to November, but also in the other months the rainfall is considerable. The humidity is high and its variation small, while the wind reaches a maximum during the northeast monsoon. This causes in January and February higher values of evaporation, which correspond to the rainfall. The energy balance shows the effective energy always exceeding the energy required for evaporation, causing a continious heating of the water and of the atmosphere. Under consideration of the magnitude of the heat surplus horizontal heat transfer must be assumed. The heating of the water occurs from February to May at the time of maximal heat surplus, the cooling from November to January, when the evaporation requires all available energy.

In the Celebes Sea and in the region north of New Guinea completely equalized conditions are found in agreement with its position close to the equator. The rainfall is high and occurs during the whole year with about $150 \mathrm{~mm} / \mathrm{month}$. Over the Celebes Sea from July to October a branch of the southeast monsoon is observed, bringing dryer air masses and smaller rainfall. The smaller relative humidity causes a higher evaporation. The energy balance indicates, that considerable amounts of heat are available for the heating of the water and of the atmosphere. The deep homogeneous layer, 100 and more meters north of New Guinea, absorbs this energy and the strong currents in this region transfer the heat out of it. The fact, that the temperature in this region always exceeds $28{ }^{\circ} \mathrm{C}$ is indicative of this large heat exeess. In the Celebes Sea the temperature drops from January to March below $28^{\circ} \mathrm{C}$, indicating a supply of cooler water from the Mindanao current.

\section{LITERATURE}

Albrecht, F. Monatskarten des Niederschlages, der Verdunstung und des Wasserhaushaltes im Indischen und Stillen Ozean. Berichte des Deutsch. Wetterdienstes, 29, 1951.

Brogmus, W. Eine Revision des Wasserhaushaltes der Ostsee. Kieler Meeresforschungen, 9, 1952. 
JAcoBs, W. C. The energy exchange between seai and atmosphere and some of its consequences. Bull. Scripps Inst. 6, 2, 1951.

Kimball, H. Amount of solar radiation that reaches the surface of the earth on the land and on the sea. Monthly Weather Rev. 1928.

Montgomery, R. B. Ein Versuch den vertikalen und seitlichen Austausch in der Tiefe der Sprungschicht im aquatorialen Atlantischen Ozean zu bestimmen. Ann. d. Hydrogr. 1939.

Sснотт, G. Geographie des Indischen und Stillen Ozeans, Hamburg, 1953. SvBrdRUP, H. U. a.o. The Oceans, New York, 1946.

VISSER, S. W. Meteorological Observations, Snellius Expedition, 3, 1936.

WyrtKi; K. The rainfall over the Indonesian Waters. Lemb. Meteor, d. Geophys. Verhandlingen 49, 1956.

Atlas of Climatic Charts of the Oceans. US Weather Bureau, Washington 1938.

Ocenographic and Meteorogical Observations in the China Sea. Koninkl. Nederl. Meteorol. Inst. No 115, Gravenhage 1936.

Sea Areas round Australia, Oceanographic and Meteorological Data. Koninkl. Nederl. Meteorol. Inst. No 124, Gravenhage 1949.

World Atlas of Sea Surface Temperatures. 1950. 


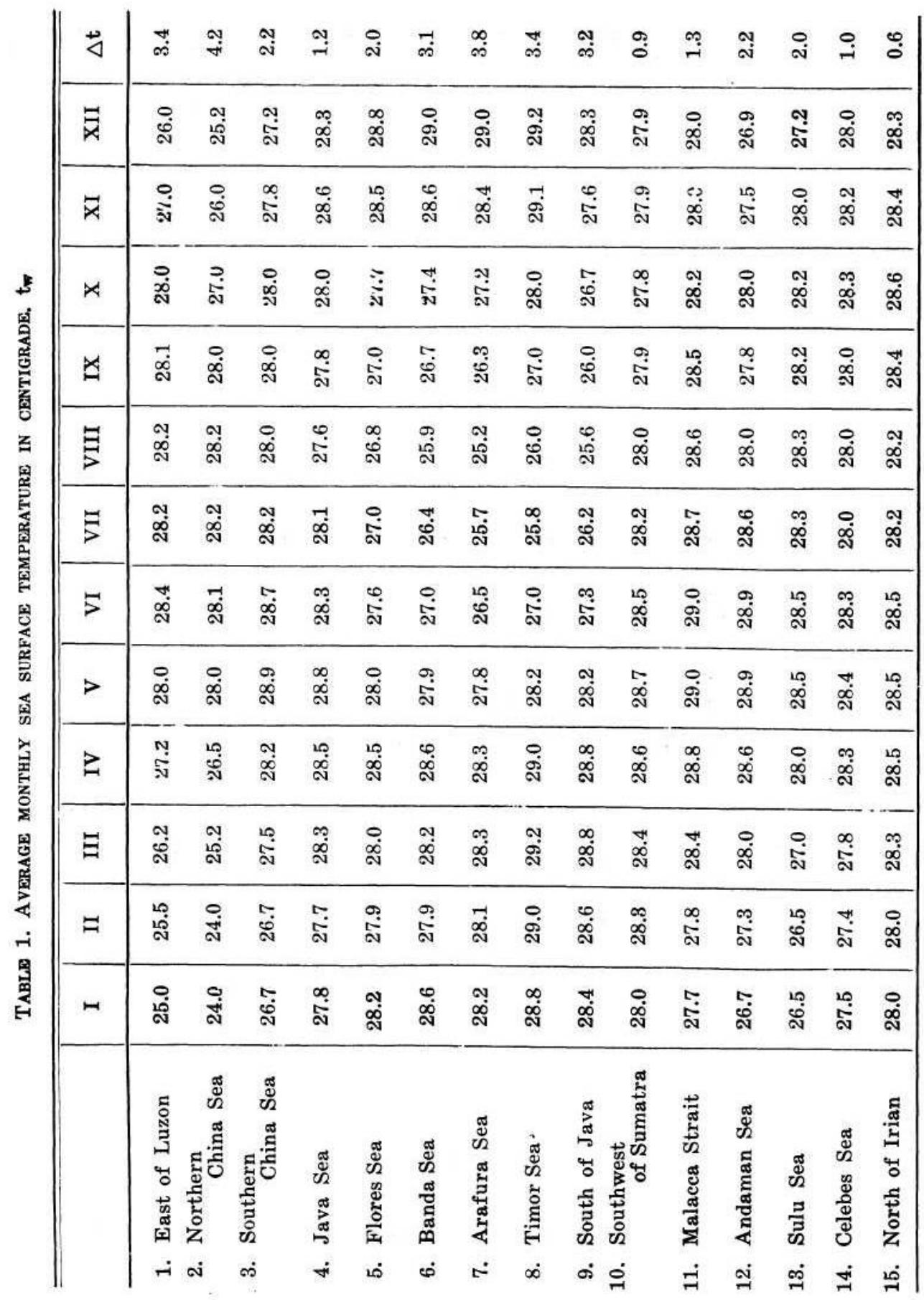




\begin{tabular}{|c|c|c|c|c|c|c|c|c|c|c|c|c|c|c|c|}
\hline$\stackrel{4}{4}$ & $\ddot{\infty}$ & $\underset{\sim}{\infty}$ & ì & $\stackrel{\infty}{\circ}$ & $\stackrel{\text { Sִ }}{-1}$ & $\stackrel{\infty}{\text { i }}$ & i̊ & $\underset{\infty}{\infty}$ & $\vec{\omega}$ & $\stackrel{\circ}{i}$ & $\underset{-1}{-1}$ & i̊ & $\stackrel{\infty}{\sim}$ & $\stackrel{\leftrightarrow}{\leftrightarrow}$ & toㅇ \\
\hline 资 & $\begin{array}{l}\infty \\
\text { ఎ̊ } \\
\text { ลे }\end{array}$ & مُ & $\stackrel{\stackrel{\leftrightarrow}{\sim}}{\text { ¿ }}$ & $\underset{\stackrel{N}{\sim}}{\stackrel{\infty}{\sim}}$ & $\begin{array}{l}10 \\
\infty \\
\infty \\
\text { a }\end{array}$ & 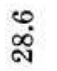 & $\underset{\infty}{\stackrel{\infty}{N}}$ & ஷ्ञ & $\underset{\infty}{\infty}$ & $\underset{\stackrel{\sim}{\sim}}{\stackrel{\sim}{\sim}}$ & 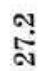 & $\stackrel{\mathscr{d}}{\circ}$ & $\underset{\text { ஸे }}{\text { ஸे }}$ & 悹 & 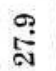 \\
\hline$\vec{x}$ & $\begin{array}{l}\infty \\
\stackrel{\sim}{\sim}\end{array}$ & $\begin{array}{l}\stackrel{0}{\circ} \\
\stackrel{\leftrightarrow}{S}\end{array}$ & $\underset{\mathrm{S}}{\stackrel{\Delta}{\Delta}}$ & $\begin{array}{l}\stackrel{\infty}{d} \\
\underset{N}{0}\end{array}$ & $\underset{\infty}{\infty} \underset{\infty}{\infty}$ & $\begin{array}{c}\infty \\
\stackrel{\infty}{\infty} \\
\text { de }\end{array}$ & $\vec{\infty}$ & 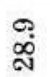 & 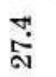 & 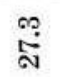 & 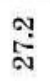 & 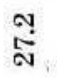 & $\stackrel{\infty}{\stackrel{\sim}{N}}$ & 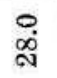 & $\vec{\infty}$ \\
\hline$x$ & స్ & $\begin{array}{l}\infty \\
\stackrel{\infty}{0}\end{array}$ & $\underset{\stackrel{N}{N}}{\check{S}}$ & $\underset{\sim}{\stackrel{\infty}{\leftarrow}}$ & $\underset{\mathrm{N}}{\stackrel{10}{\sim}}$ & $\underset{\text { స్ }}{\stackrel{N}{~}}$ & 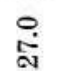 & $\underset{\sim}{\stackrel{\infty}{\sim}}$ & $\begin{array}{l}10 \\
\text { d़ी }\end{array}$ & $\underset{\text { సุ }}{\text { స }}$ & $\underset{\sim}{\stackrel{\sim}{\sim}}$ & 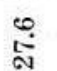 & 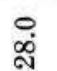 & 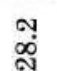 & $\begin{array}{l}\stackrel{\sim}{\infty} \\
\stackrel{\infty}{d}\end{array}$ \\
\hline 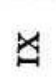 & 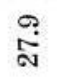 & $\underset{\stackrel{\leftrightarrow}{\sim}}{\stackrel{\sigma}{~}}$ & 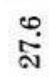 & $\stackrel{\leftrightarrow}{\stackrel{\leftrightarrow}{\Delta}}$ & $\begin{array}{l}\text { @) } \\
\stackrel{\leftrightarrow}{\circ}\end{array}$ & 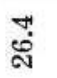 & $\begin{array}{l}\text { Nุ } \\
\text { ़ֻ }\end{array}$ & 宗 & 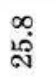 & 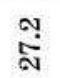 & 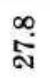 & 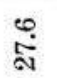 & $\stackrel{\infty}{\stackrel{\leftrightarrow}{\sim}}$ & $\underset{\text { సุ }}{\text { N }}$ & $\stackrel{\text { ㅇ }}{\stackrel{\text { d }}{2}}$ \\
\hline$\stackrel{\Xi}{\rightrightarrows}$ & $\begin{array}{l}\stackrel{0}{\infty} \\
\stackrel{d}{N}\end{array}$ & $\vec{d}$ & $\underset{\stackrel{\sim}{\sim}}{\stackrel{\infty}{\sim}}$ & 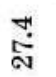 & $\begin{array}{l}\mathscr{\leftrightarrow} \\
\stackrel{\leftrightarrow}{\circ}\end{array}$ & $\begin{array}{l}\infty \\
\stackrel{\leftrightarrow}{\mathrm{d}}\end{array}$ & 峁 & $\begin{array}{l}\text { ণุ. } \\
\text { के }\end{array}$ & 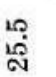 & 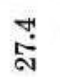 & 这 & 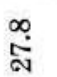 & 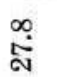 & 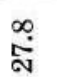 & 足 \\
\hline 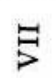 & $\underset{\infty}{\infty}$ & $\stackrel{\circ}{\stackrel{\leftrightarrow}{\oplus}}$ & $\begin{array}{l}\stackrel{\circ}{\infty} \\
\stackrel{\infty}{N}\end{array}$ & 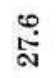 & 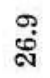 & 哭 & $\begin{array}{l}\text { 影 } \\
\text { an }\end{array}$ & 完 & $\begin{array}{l}7-1 \\
\stackrel{\omega}{*}\end{array}$ & $\underset{\text { ஸे }}{\stackrel{0}{~}}$ & $\underset{\text { ஸุ }}{\text { ஸे }}$ & $\begin{array}{l}\infty \\
\stackrel{\infty}{\sim} \\
\stackrel{d}{2}\end{array}$ & 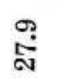 & 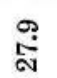 & $\stackrel{19}{\stackrel{\text { N }}{\text { N }}}$ \\
\hline 5 & 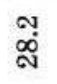 & 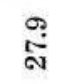 & $\begin{array}{l}\mathscr{\infty} \\
\stackrel{\infty}{\infty}\end{array}$ & $\begin{array}{l}\text { ○् } \\
\text { ळे }\end{array}$ & 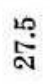 & $\begin{array}{l}\text { o } \\
\text { के }\end{array}$ & 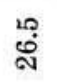 & હે & 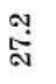 & $\begin{array}{l}\stackrel{\circ}{\dot{d}} \\
\stackrel{\mathrm{d}}{ }\end{array}$ & $\begin{array}{l}\text { ஸे } \\
\text { ஸे }\end{array}$ & $\begin{array}{l}\stackrel{10}{\infty} \\
\stackrel{\infty}{\infty}\end{array}$ & 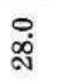 & - & 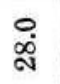 \\
\hline$>$ & $\stackrel{\infty}{\stackrel{\infty}{\sim}}$ & $\underset{\stackrel{N}{\sim}}{\stackrel{\infty}{\sim}}$ & $\begin{array}{l}10 \\
\stackrel{\infty}{\infty} \\
\stackrel{\infty}{0}\end{array}$ & $\underset{\infty}{\infty}$ & 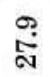 & 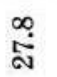 & 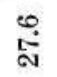 & 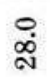 & 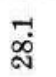 & $\begin{array}{l}\text { ã } \\
\underset{\sim}{\infty}\end{array}$ & 恕 & 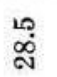 & 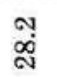 & 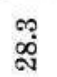 & $\underset{\stackrel{\infty}{\infty}}{\stackrel{\infty}{a}}$ \\
\hline$\geq$ & $\begin{array}{l}10 \\
\stackrel{\leftrightarrow}{\infty} \\
\text { N }\end{array}$ & 过 & $\stackrel{\circ}{\stackrel{\infty}{N}}$ & $\begin{array}{l}\stackrel{0}{0} \\
\stackrel{\infty}{\Delta}\end{array}$ & $\underset{\text { D. }}{\overrightarrow{0}}$ & 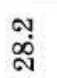 & 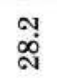 & 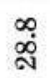 & $\begin{array}{l}10 \\
\stackrel{0}{\infty} \\
\stackrel{\infty}{0}\end{array}$ & $\stackrel{\circ}{\stackrel{\infty}{\oplus}}$ & $\stackrel{\stackrel{\circ}{\infty}}{\stackrel{\infty}{N}}$ & 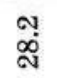 & 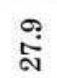 & 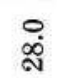 & $\begin{array}{l}\stackrel{0}{\dot{d}} \\
\text { N }\end{array}$ \\
\hline 㭅 & 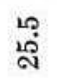 & 卤 & $\stackrel{\Re}{\stackrel{\leftrightarrow}{\sim}}$ & 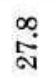 & 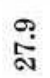 & 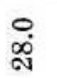 & $\begin{array}{l}\stackrel{\infty}{\infty} \\
\stackrel{\infty}{0}\end{array}$ & 六 & $\begin{array}{l}\stackrel{0}{\dot{⿰}} \\
\stackrel{\dot{\Phi}}{2}\end{array}$ & 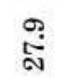 & స్ & 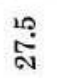 & $\begin{array}{l}\text { o } \\
\text { कू }\end{array}$ & $\underset{\stackrel{\sim}{\sim}}{\stackrel{L}{\sim}}$ & 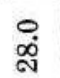 \\
\hline$\exists$ & 옹 & 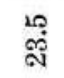 & $\begin{array}{l}\text { ng } \\
\text { ஸे }\end{array}$ & $\stackrel{10}{\stackrel{10}{\sim ̆}}$ & స్ & $\begin{array}{l}\infty \\
\stackrel{\sim}{\sim} \\
\end{array}$ & $\stackrel{\circ}{\stackrel{\infty}{N}}$ & $\begin{array}{l}\infty \\
\stackrel{\infty}{\infty} \\
\text { d. }\end{array}$ & $\begin{array}{l}100 \\
\stackrel{10}{\text { d. }}\end{array}$ & ঙ & $\underset{\text { ஸे }}{\stackrel{10}{S}}$ & $\begin{array}{l}\text { ò } \\
\dot{d}\end{array}$ & $\underset{\leftrightarrow}{\stackrel{\leftrightarrow}{\leftrightarrow}}$ & $\stackrel{\text { ஸे }}{\text {. }}$ & 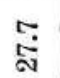 \\
\hline$H$ & $\stackrel{\infty}{\stackrel{\sim}{+}}$ & $\underset{\approx}{\infty}$ & $\begin{array}{l}\mathscr{0} \\
\stackrel{\leftrightarrow}{\circ}\end{array}$ & $\underset{\text { 岕 }}{\text {. }}$ & $\underset{\mathrm{N}}{\stackrel{\circ}{\mathrm{N}}}$ & $\begin{array}{l}\infty \\
\stackrel{\infty}{\infty}\end{array}$ & $\begin{array}{l}\stackrel{0}{\infty} \\
\stackrel{\infty}{0}\end{array}$ & $\begin{array}{l}0 \\
\infty \\
\stackrel{D}{N}\end{array}$ & $\underset{\infty}{\infty}$ & 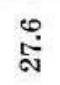 & 品 & 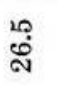 & تே. & 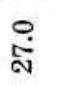 & 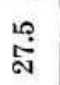 \\
\hline & 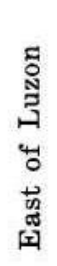 & 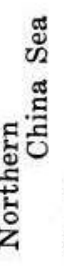 & 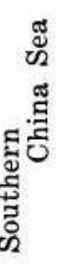 & 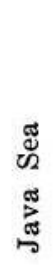 & 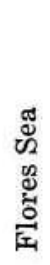 & 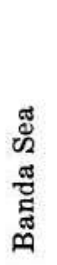 & 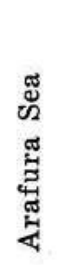 & 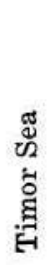 & 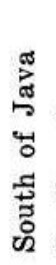 & 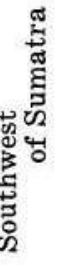 & 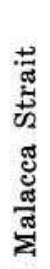 & 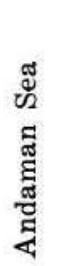 & 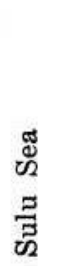 & 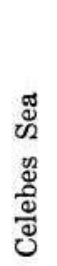 & 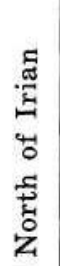 \\
\hline & -i & & ¿) & मं & เด & 0 & $\stackrel{\circ}{\circ}$ & $\infty$ & $\dot{0}$ & $\dot{\theta}$ & - & ๙્่ & $\stackrel{\oplus}{\oplus}$ & $\underset{\sim}{-}$ & $\stackrel{\dot{\rho}}{\sim}$ \\
\hline
\end{tabular}




\begin{tabular}{|c|c|c|c|c|c|c|c|c|c|c|c|c|c|c|c|}
\hline$\stackrel{\triangleleft}{\triangleleft}$ & $\ddot{n}$ & $\stackrel{\text { งุ }}{\text { ช }}$ & ผี & $\stackrel{\text { N̦ }}{\sim}$ & $\stackrel{\text { iे }}{\text { in }}$ & $\vec{\infty}$ & $\stackrel{\infty}{\infty}$ & $\overrightarrow{\text { m. }}$ & ๗ૈ & $\stackrel{\circ}{0}$ & $\stackrel{\leftrightarrow}{\pi}$ & สุ & $\stackrel{\circ}{\text { ì }}$ & $\stackrel{\circ}{-1}$ & $\stackrel{\circ}{\circ}$ \\
\hline$\Xi$ & 通 & 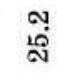 & $\underset{\text { సั }}{\stackrel{N}{N}}$ & 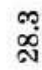 & $\begin{array}{l}\infty \\
\infty \\
\stackrel{\infty}{N}\end{array}$ & $\stackrel{\circ}{\stackrel{S}{S}}$ & 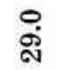 & ๙ุ & 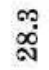 & 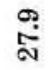 & $\begin{array}{l}\dot{0} \\
\stackrel{\infty}{\text { Dे }}\end{array}$ & $\begin{array}{l}\text { के } \\
\text { की }\end{array}$ & ঙุ & $\begin{array}{l}\text { के } \\
\text { aे }\end{array}$ & 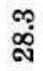 \\
\hline $\bar{x}$ & 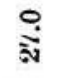 & : & $\underset{\sim}{\stackrel{\infty}{N}}$ & $\begin{array}{l}0 \\
\stackrel{\infty}{\omega} \\
\stackrel{\omega}{N}\end{array}$ & 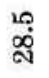 & $\stackrel{\mathscr{D}}{\stackrel{\infty}{\infty}}$ & $\underset{\infty}{\stackrel{\infty}{\infty}}$ & 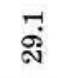 & 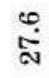 & 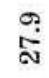 & 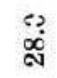 & 㝵 & 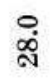 & $\underset{\substack{\infty \\
\text { a }}}{ }$ & $\underset{\infty}{\stackrel{\infty}{d}}$ \\
\hline$x$ & 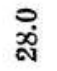 & 忘 & $\stackrel{0}{\stackrel{0}{0}}$ & 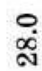 & 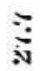 & $\underset{\mathrm{N}}{\stackrel{\vec{N}}{\mathrm{~N}}}$ & 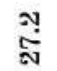 & $\begin{array}{l}\stackrel{0}{d} \\
\text { do }\end{array}$ & 뭉 & $\underset{\underset{\sim}{\sim}}{\infty}$ & ஸั & 怘 & $\underset{\infty}{\infty}$ & 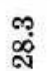 & 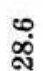 \\
\hline 死 & $\vec{\infty}$ & 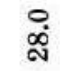 & $\begin{array}{l}\stackrel{\circ}{\circ} \\
\stackrel{0}{N}\end{array}$ & 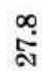 & 灾 & 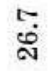 & 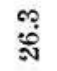 & $\stackrel{\stackrel{\dot{N}}{ }}{ }$ & 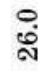 & 灾 & $\begin{array}{l}\text { Lo } \\
\stackrel{\infty}{\infty}\end{array}$ & $\underset{\stackrel{\sim}{\sim}}{\stackrel{\infty}{\sim}}$ & $\begin{array}{l}\text { N̦ } \\
\underset{\sim}{\infty}\end{array}$ & $\begin{array}{l}\stackrel{0}{\infty} \\
\stackrel{\infty}{=}\end{array}$ & 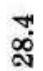 \\
\hline 寻 & $\begin{array}{l}\stackrel{\infty}{\infty} \\
\stackrel{\infty}{\infty}\end{array}$ & స్ & $\stackrel{\circ}{\stackrel{\infty}{d}}$ & ث્. & $\begin{array}{l}\infty \\
\text { की }\end{array}$ & 呙 & $\begin{array}{l}\text { ஸุ } \\
\text { เึ่ }\end{array}$ & $\begin{array}{l}\stackrel{\leftrightarrow}{.} \\
\text { बे }\end{array}$ & 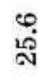 & $\begin{array}{l}\text { O̊ } \\
\stackrel{\infty}{0}\end{array}$ & $\begin{array}{l}\stackrel{0}{0} \\
\stackrel{\infty}{\sim}\end{array}$ & $\underset{\stackrel{\infty}{\infty}}{\stackrel{0}{d}}$ & $\underset{\sim}{\infty} \underset{\infty}{\infty}$ & 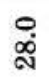 & $\underset{\infty}{\stackrel{\sim}{\infty}}$ \\
\hline 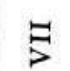 & $\underset{\infty}{\text { ஸे }}$ & $\underset{\infty}{\infty}$ & $\begin{array}{l}\stackrel{\text { s. }}{\infty} \\
\text { }\end{array}$ & :-1 & $\stackrel{\text { ஸे }}{\text { 亡े }}$ & 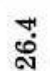 & เ & $\begin{array}{l}\infty \\
\text { Iิ } \\
\text { No }\end{array}$ & ़ֻ & 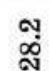 & $\stackrel{\mathfrak{s}}{\mathbf{s}}$ & $\stackrel{\infty}{\infty}$ & $\stackrel{\infty}{\infty}$ & $\stackrel{0}{\infty}$ & ণุ \\
\hline 5 & $\underset{\infty}{\infty}$ & i্ & 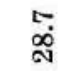 & 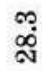 & 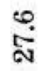 & 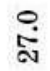 & $\begin{array}{l}10 \\
\text { ô }\end{array}$ & $\stackrel{\stackrel{\dot{N}}{ }}{\text { }}$ & 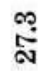 & $\begin{array}{l}10 \\
\stackrel{\infty}{\infty}\end{array}$ & 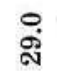 & $\begin{array}{l}\stackrel{0}{0} \\
\dot{\infty}\end{array}$ & 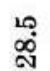 & $\underset{\substack{\infty \\
\stackrel{\infty}{\infty}}}{ }$ & $\begin{array}{l}10 \\
\infty \\
\infty \\
\infty\end{array}$ \\
\hline$>$ & $\begin{array}{l}0 \\
\stackrel{\infty}{N}\end{array}$ & $\underset{\stackrel{\infty}{\circ}}{\stackrel{\circ}{0}}$ & 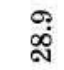 & $\begin{array}{l}\infty \\
\infty \\
\stackrel{\infty}{\sim}\end{array}$ & $\begin{array}{l}\text { Dे } \\
\text { : }\end{array}$ & 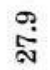 & $\stackrel{\infty}{\stackrel{\infty}{\sim}}$ & 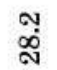 & $\begin{array}{l}\text { ஸุ } \\
\text { ळ }\end{array}$ & $\stackrel{\leftrightarrow}{\infty}$ & $\stackrel{\circ}{\stackrel{\text { S }}{.}}$ & 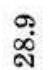 & 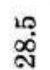 & 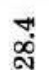 & $\begin{array}{l}L_{0}^{0} \\
\stackrel{\infty}{*}\end{array}$ \\
\hline$Z$ & $\stackrel{N}{\stackrel{ஸ}{N}}$ & 占 & $\underset{\substack{\infty \\
\sim}}{\sim}$ & 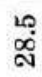 & & $\begin{array}{l}\mathscr{D} \\
\stackrel{\infty}{N}\end{array}$ & $\begin{array}{l}m_{\infty} \\
\dot{\omega}\end{array}$ & ஓ्. & $\begin{array}{l}\infty \\
\stackrel{\infty}{\infty} \\
\stackrel{\infty}{\infty}\end{array}$ & 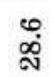 & 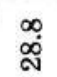 & $\begin{array}{l}\ddot{\infty} \\
\stackrel{\infty}{\infty}\end{array}$ & 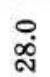 & $\underset{\infty}{\infty}$ & 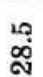 \\
\hline$\Xi$ & $\begin{array}{l}\text { ขึ } \\
\text { कै }\end{array}$ & 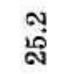 & $\underset{\sim}{\stackrel{10}{\sim}}$ & $\begin{array}{c}\infty \\
\infty \\
\infty\end{array}$ & 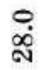 & $\begin{array}{l}\text { N̦ } \\
\stackrel{\infty}{\infty}\end{array}$ & $\underset{\substack{\infty \\
\infty}}{\infty}$ & ๙ุ & $\begin{array}{l}\infty \\
\infty \\
\stackrel{\infty}{\infty}\end{array}$ & $\underset{\stackrel{\omega}{\infty}}{\not d}$ & $\underset{\stackrel{\infty}{\infty}}{\not{d}}$ & $\begin{array}{l}\stackrel{0}{ } \\
\stackrel{\text { d }}{0}\end{array}$ & 完 & $\begin{array}{l}\infty \\
\stackrel{\text { స }}{\leftarrow}\end{array}$ & 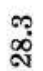 \\
\hline$\approx$ & 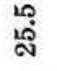 & $\stackrel{\circ}{\stackrel{N}{*}}$ & 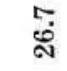 & స్ & 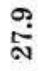 & 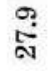 & $\underset{\infty}{\stackrel{0}{0}}$ & ஷें & 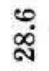 & $\begin{array}{l}\infty \\
\stackrel{\infty}{\oplus}\end{array}$ & $\stackrel{\infty}{\stackrel{\sim}{\sim}}$ & 号 & 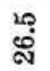 & $\underset{\text { స్ }}{\stackrel{\sim}{2}}$ & $\stackrel{\circ}{\stackrel{\leftrightarrow}{\circ}}$ \\
\hline 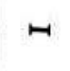 & ค่ำ & సึ. & 萬 & $\stackrel{\infty}{\stackrel{\infty}{\sim}}$ & 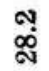 & $\begin{array}{l}\text { d. } \\
\stackrel{\infty}{0}\end{array}$ & $\underset{\infty}{\infty}$ & $\begin{array}{l}\infty \\
\infty \\
\stackrel{\infty}{\infty}\end{array}$ & $\underset{\infty}{\stackrel{\infty}{\infty}}$ & $\stackrel{0}{\infty}$ & 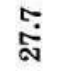 & $\vec{\leftrightarrow}$ & 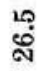 & 疋 & $\underset{\infty}{\stackrel{\circ}{\text { d }}}$ \\
\hline & 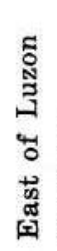 & 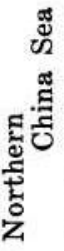 & 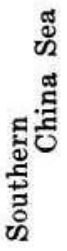 & 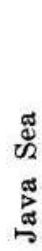 & 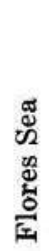 & 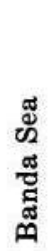 & 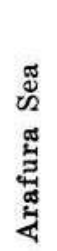 & 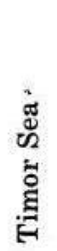 & 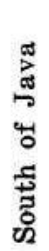 & 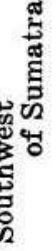 & 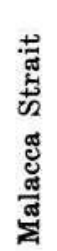 & 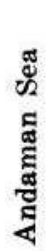 & 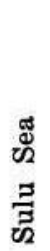 & 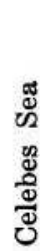 & 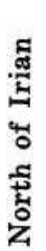 \\
\hline & - & & ळ & + & $10^{\circ}$ & ம) & $\stackrel{2}{ }$ & $\infty$ & & & $\vec{f}$ & ำ & $\stackrel{\oplus}{\mathfrak{I}}$ & $\underset{\sim}{ }$ & 200 \\
\hline
\end{tabular}




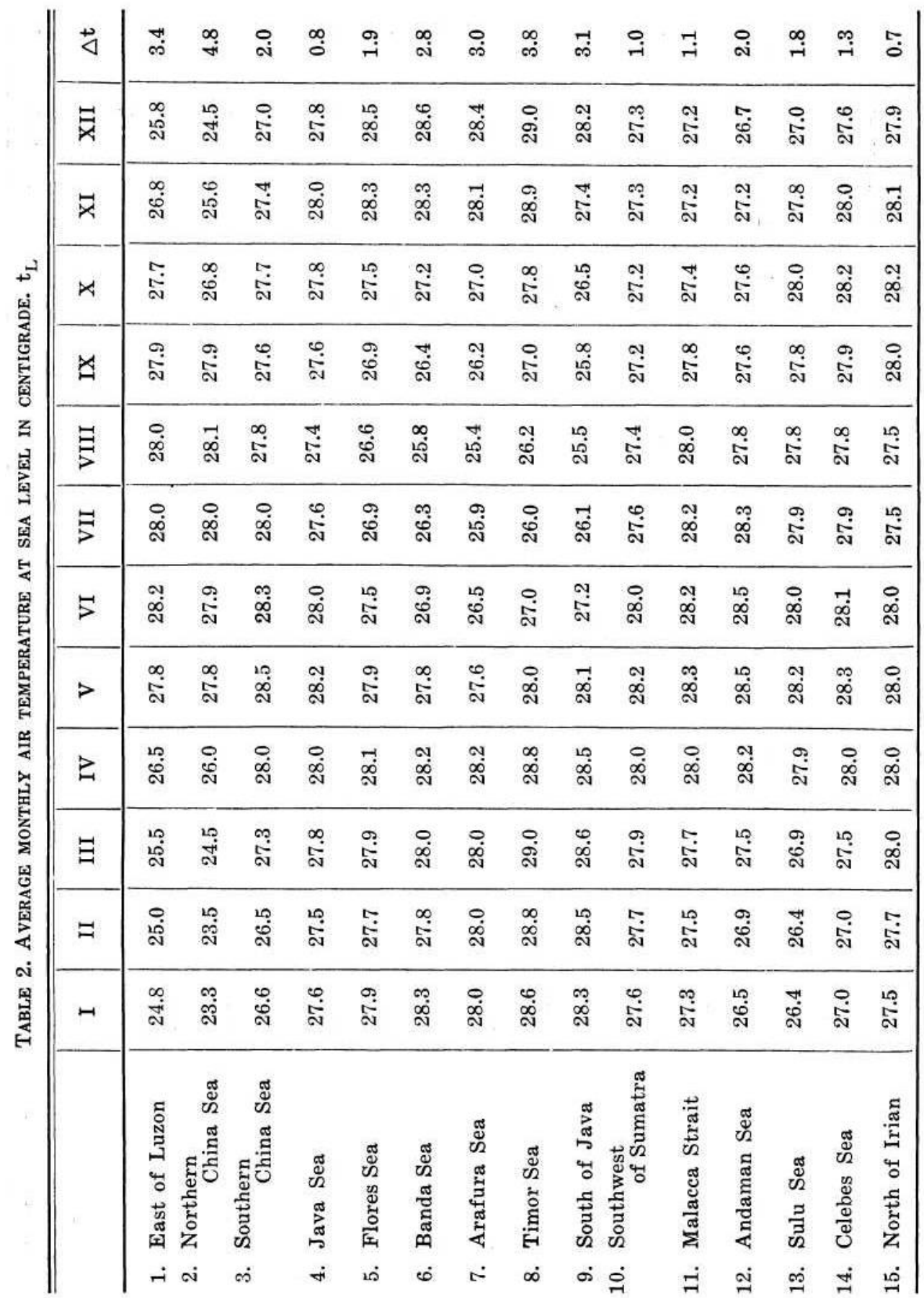




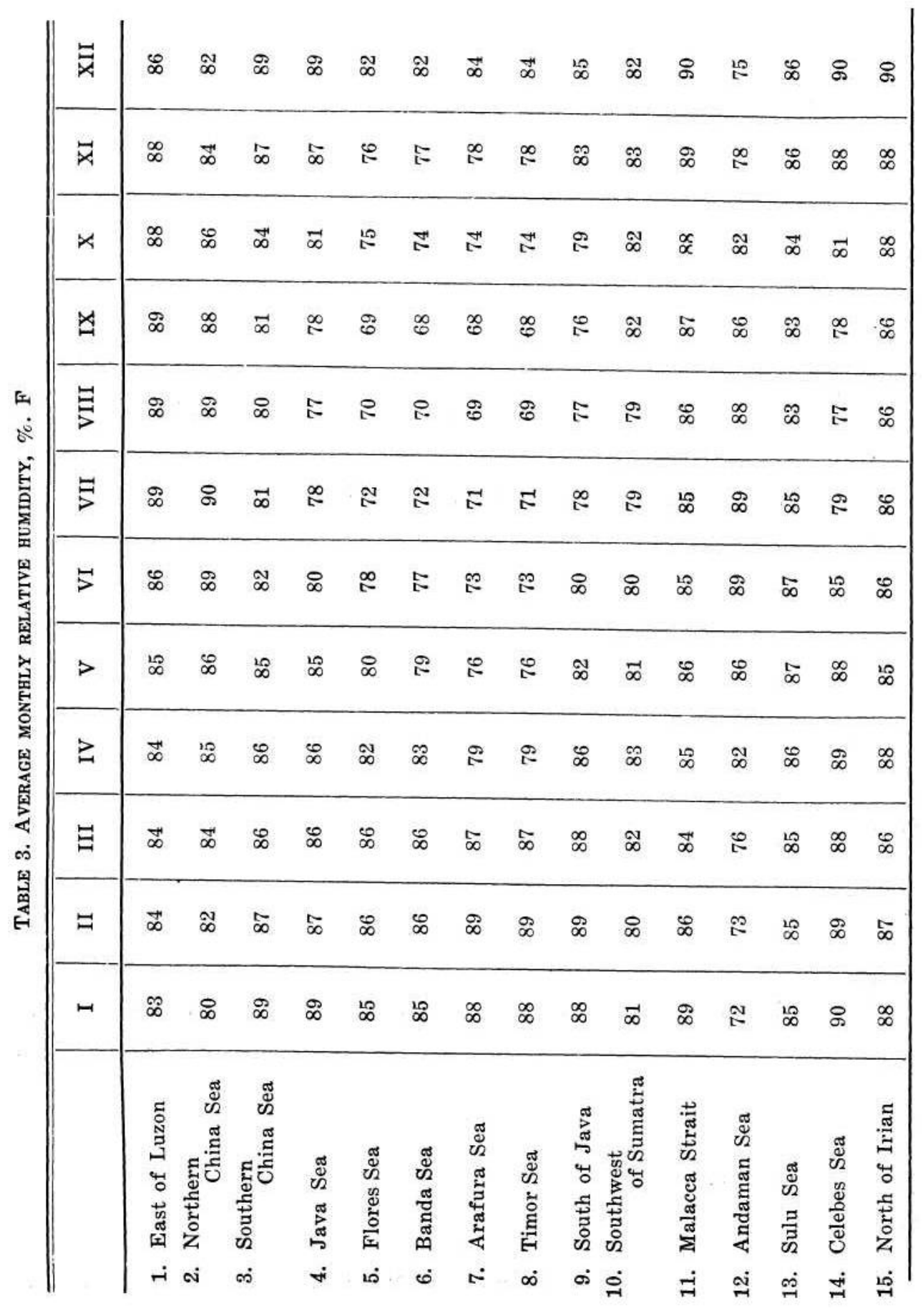




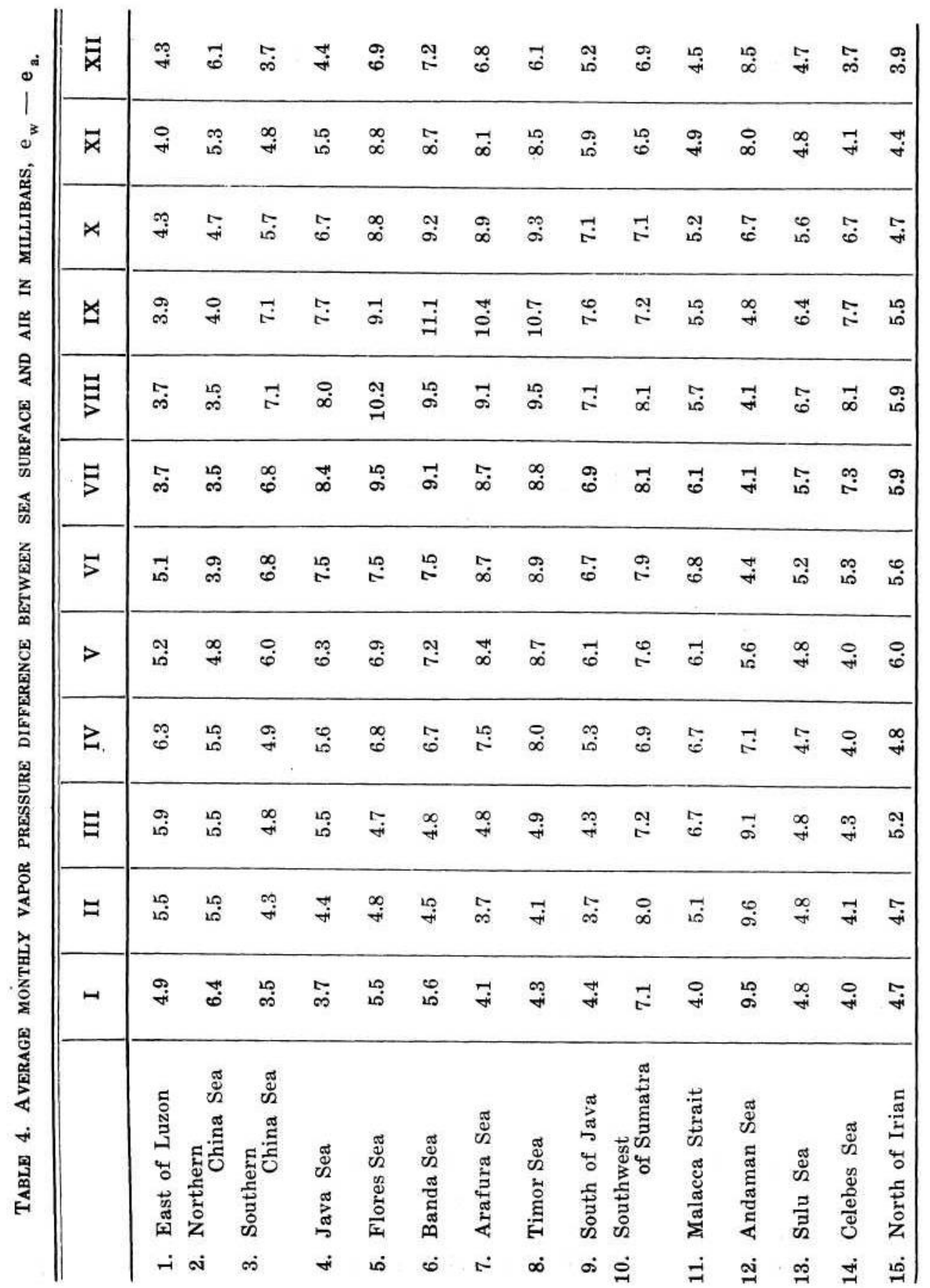




\begin{tabular}{|c|c|c|c|c|c|c|c|c|c|c|c|c|c|c|c|}
\hline 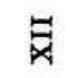 & $\stackrel{0}{=}$ & $\stackrel{\oplus}{=}$ & 占 & $\stackrel{5}{+}$ & $\stackrel{\oplus}{\oplus}$ & $\stackrel{\oplus}{\infty}$ & $\stackrel{9}{\oplus}$ & $\stackrel{\infty}{\infty}$ & 5 & $\stackrel{\Re}{\sim}$ & $\stackrel{10}{+1}$ & 7 & ঙ̣ & 7 & $\stackrel{\infty}{\sim}$ \\
\hline $\bar{x}$ & 5 & $\stackrel{\mathscr{I}}{\stackrel{I}{\mid}}$ & 10. & คุ & $\stackrel{10}{\infty}$ & $\overrightarrow{7}$ & 5 & $\vec{F}$ & 5 & $\stackrel{10}{\rightarrow+}$ & $\stackrel{\infty}{\infty}$ & 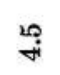 & $\stackrel{\circ}{\circ}$ & $\overrightarrow{f i}$ & 든 \\
\hline$x$ & 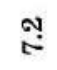 & ุㅜ & 5 & 7 & Fi & ํํㅇำ & $\stackrel{0}{\circ}$ & $\stackrel{\infty}{\stackrel{\infty}{i f}}$ & $\stackrel{\text { શ̣ }}{\sim}$ & $\overrightarrow{7}$ & $=$ & $\stackrel{20}{+}$ & 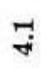 & $\stackrel{\oplus}{\infty}$ & $\underset{\substack{\infty \\
\stackrel{\infty}{0}}}{ }$ \\
\hline$\not \ddot{a}$ & อִ 20 & थִ & 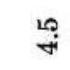 & ஜٌ & فำ & : & $\stackrel{\text { ๙̣ }}{\sim}$ & $\stackrel{10}{6}$ & $\stackrel{\infty}{\infty}$ & $\overrightarrow{7 i}$ & $\stackrel{10}{+\infty}$ & เి & $\stackrel{5}{7}$ & $\stackrel{\rho}{\infty}$ & ขै \\
\hline$\stackrel{\Xi}{\Xi}$ & $\stackrel{\infty}{\infty}$ & 吕 & ஷึ่ & 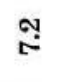 & $\underset{10}{\infty}$ & $\stackrel{20}{6}$ & 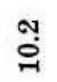 & $\stackrel{\infty}{\infty}$ & $\stackrel{\bullet}{\Rightarrow}$ & $\stackrel{\infty}{+i}$ & 궁 & $\stackrel{\circ}{\sigma}$ & F & $\stackrel{0}{\infty}$ & શุ \\
\hline$\exists$ & $\stackrel{0}{0}$ & $\stackrel{\infty}{\infty}$ & เo & ○. & $\stackrel{0}{0}$ & ભ̣ & ஸุ & $\stackrel{\mathscr{0}}{\stackrel{-}{0}}$ & ஸุ & $\mathscr{m}$ & $\stackrel{\infty}{\sim}$ & ö & 5 & $\overrightarrow{7}$ & $\stackrel{7}{7}$ \\
\hline 5 & 굼 & ஜึ. & $\overrightarrow{+i}$ & 10 & 20 & : & $\mathscr{\infty}_{\infty}$ & $\stackrel{\infty}{\infty}$ & 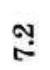 & $\stackrel{10 \rho}{\infty}$ & 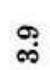 & ஸุ & $\overrightarrow{7}$ & 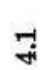 & $\stackrel{s}{\infty}$ \\
\hline$>$ & فم & f & $\stackrel{\infty}{\infty}$ & $\underset{\infty}{\infty}$ & $\stackrel{+0}{*}$ & F & 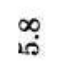 & $\stackrel{5}{+}$ & $\stackrel{\infty}{\stackrel{\infty}{\infty}}$ & $\stackrel{10}{\infty}$ & $\stackrel{\operatorname{Lg}}{\infty}$ & $\stackrel{10}{\stackrel{10}{0}}$ & 占 & के & 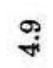 \\
\hline$\geq$ & స్ & i⿱ & மூ & فे & $\stackrel{\oplus}{\infty}$ & ه़ & $\vec{F}$ & $\overrightarrow{7}$ & 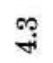 & $\stackrel{\oplus}{\infty}$ & 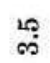 & $\vec{j}$ & 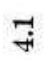 & $\stackrel{\leftrightarrow}{\circ}$ & $\stackrel{\leftrightarrow}{\infty}$ \\
\hline 寻 & $\stackrel{\text { \ุ }}{\sim}$ & $\stackrel{0}{0}$ & ־ & $\stackrel{\oplus}{\circ}$ & $\stackrel{\circ}{\infty}$ & $\exists$ & $\stackrel{\leftrightarrow}{\rightarrow}$ & $\overrightarrow{10}$ & $\check{+}$ & $\underset{\infty}{\infty}$ & 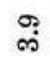 & $\stackrel{100}{\infty}$ & 5 & $\stackrel{\leftrightarrow}{\infty}$ & $\stackrel{\leftrightarrow}{\stackrel{\infty}{\infty}}$ \\
\hline 曰 & ஸุ & $\stackrel{10}{\infty}$ & $\stackrel{0}{0}$ & $\overrightarrow{7}$ & $\stackrel{10}{+\infty}$ & F & $\stackrel{\infty}{+}$ & 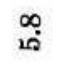 & ڤ̊ & $\underset{\infty}{\infty}$ & के & $\underset{\infty}{\infty}$ & 足 & $\overrightarrow{7}$ & † \\
\hline$H$ & $\stackrel{\circ}{=}$ & ๙ิ & $\stackrel{100}{60}$ & ஜึ & 5 & ri & เم & $\stackrel{0}{0}$ & ڤ̊. & $\stackrel{\infty}{\infty}$ & 7 & 5 & $\stackrel{\infty}{0}$ & $F$ & 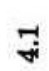 \\
\hline & 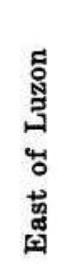 & 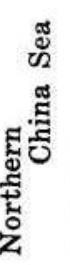 & 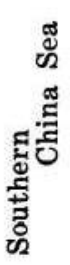 & 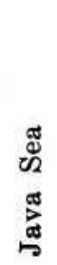 & 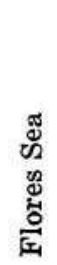 & 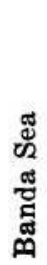 & 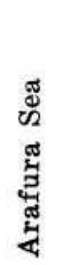 & 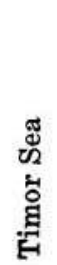 & 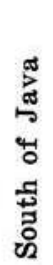 & 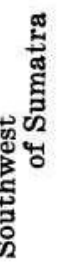 & 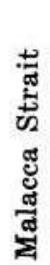 & 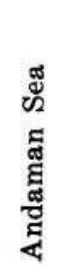 & 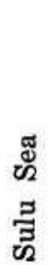 & 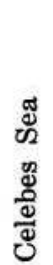 & 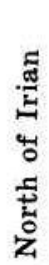 \\
\hline & $\dot{-}$ & & ळ & $+i$ & $10^{\circ}$ & $\dot{0}$ & $\stackrel{\circ}{\circ}$ & $\infty$ & $\dot{0}$ & & $\overrightarrow{7}$ & มี & $\ddot{\sim}$ & $\underset{\sim}{ }$ & $\stackrel{10}{\sim}$ \\
\hline
\end{tabular}




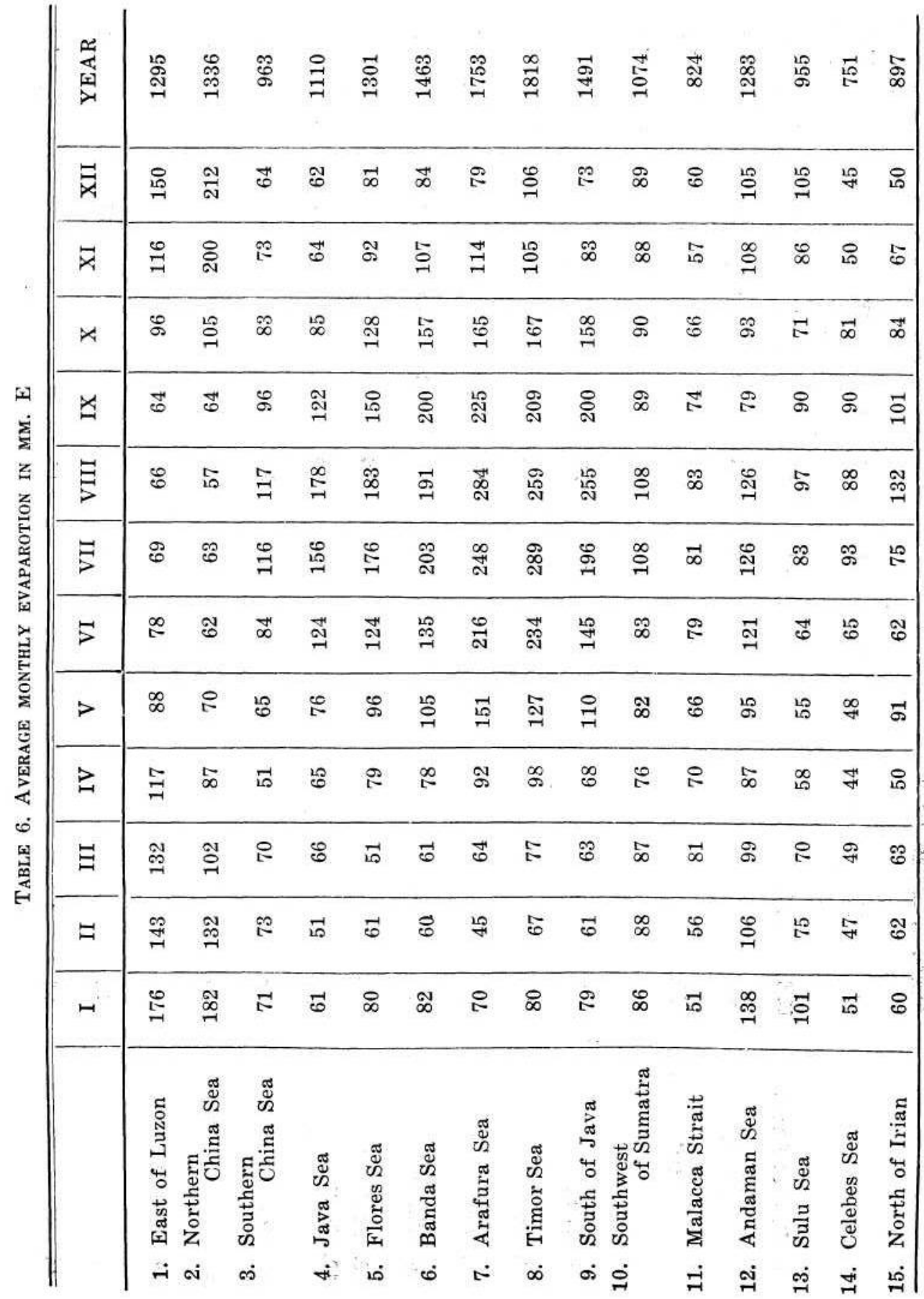




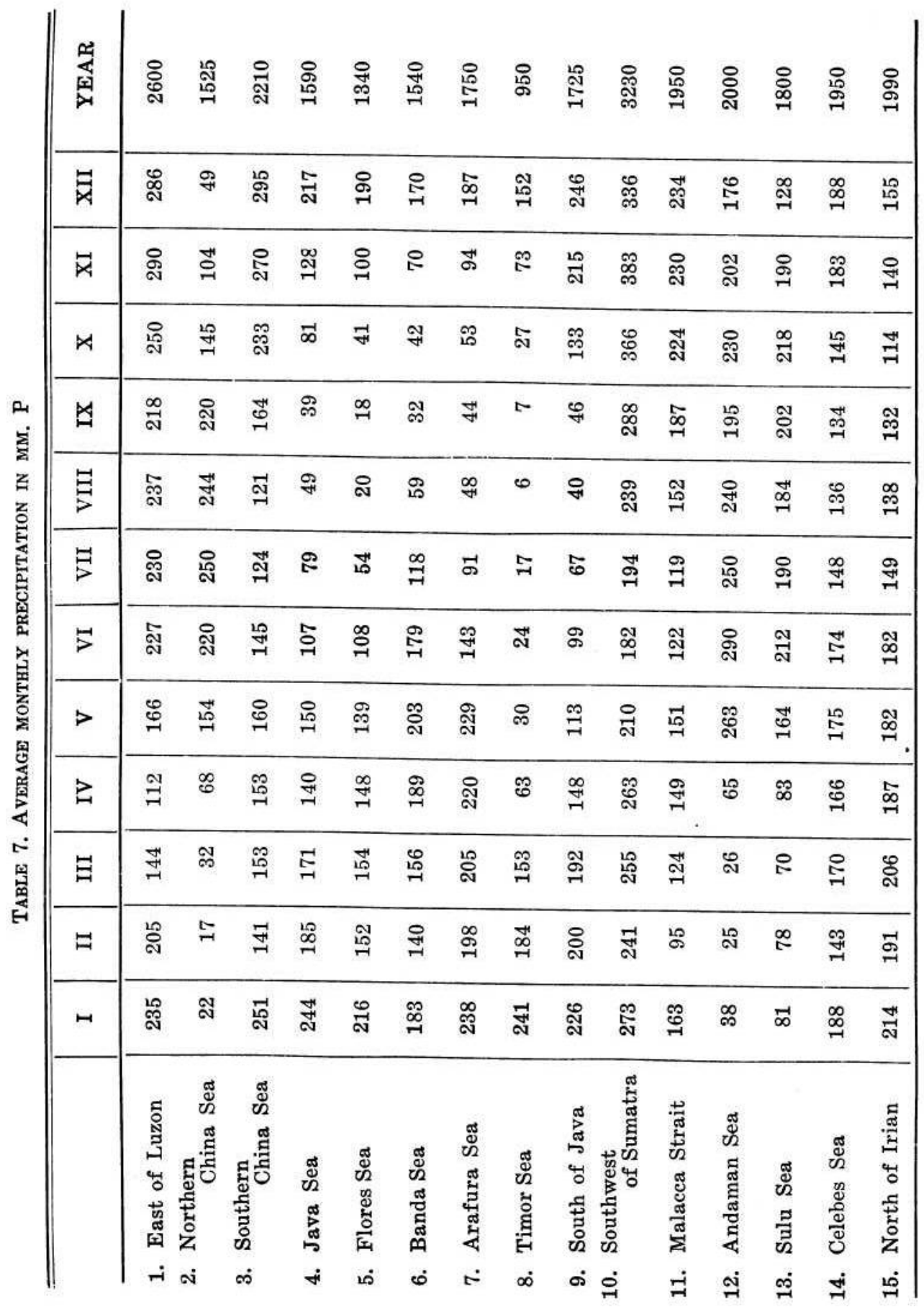




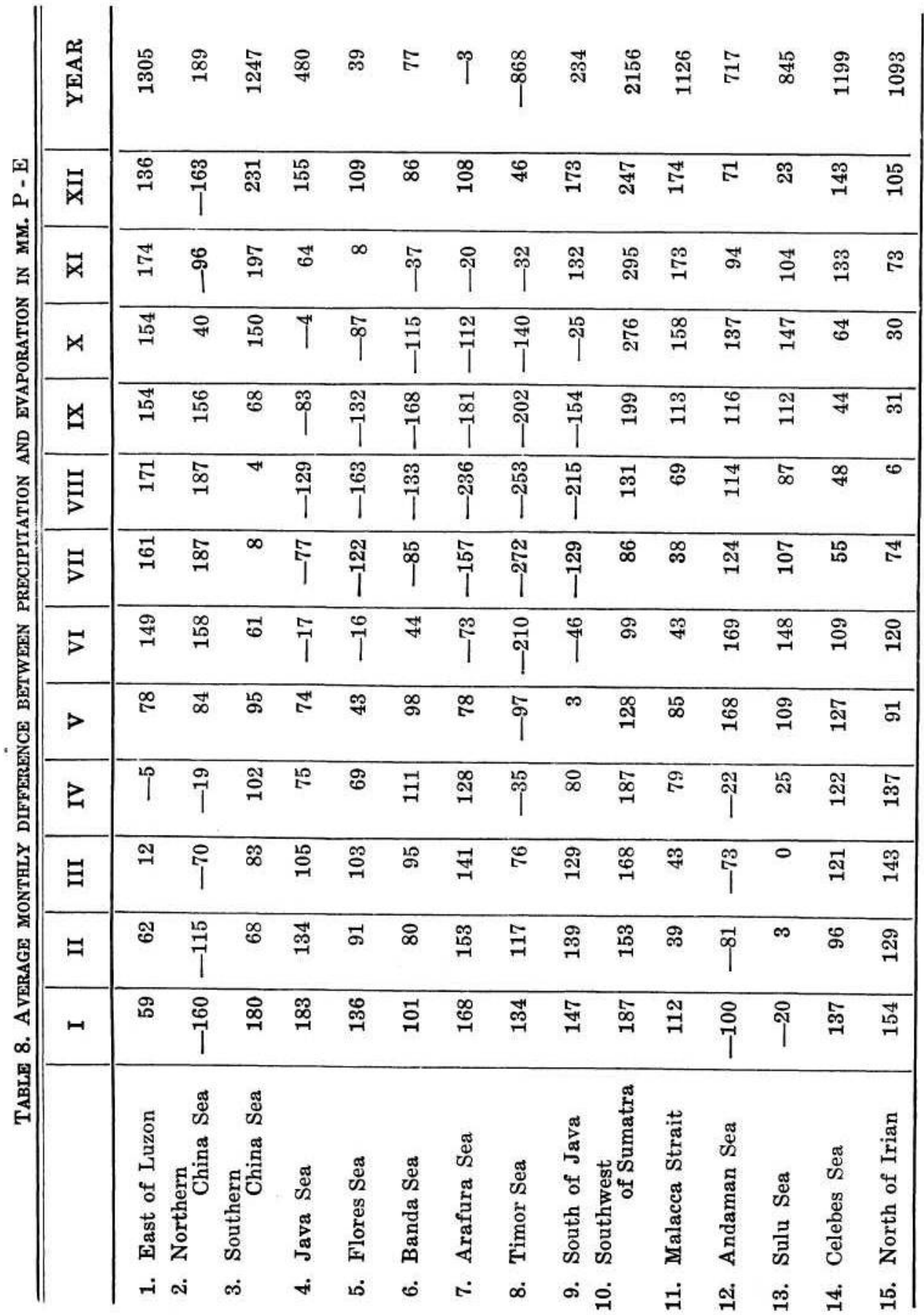




\begin{tabular}{|c|c|c|c|c|c|c|c|c|c|c|c|c|c|c|c|}
\hline 获 & ச) & 10 & 20 & $\stackrel{10}{60}$ & $\stackrel{\circ}{0}$ & $\stackrel{\circ}{\circ}$ & $\stackrel{\circ}{\circ}$ & Lִ & $\stackrel{\circ}{\circ}$ & வூ & $\stackrel{0}{0}$ & مִ & هُمْ & $\stackrel{0}{0}$ & $\stackrel{0}{0}$ \\
\hline$\vec{A}$ & $\stackrel{\circ}{0}$ & 울 & $\stackrel{\circ}{\circ}$ & $\stackrel{\circ}{\circ}$ & $\stackrel{0}{0}$ & ํㅗㅁ & فํ. & $\stackrel{10}{*}$ & مُ & & 10 & is & فึ & 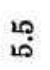 & $\stackrel{\circ}{0}$ \\
\hline$x$ & $\stackrel{0}{\circ}$ & 200 & $\stackrel{\circ}{\circ}$ & ס 20 & فم 20 & 이 & $\stackrel{\circ}{+}$ & فه & 울 & مُ & $\stackrel{100}{0}$ & $\stackrel{\circ}{0}$ & 웅 & 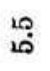 & $\stackrel{0}{0}$ \\
\hline$\not \nexists$ & $\dot{0}$ & $\dot{0}$ & $\stackrel{\circ}{\circ}$ & is & $\stackrel{20}{20}$ & $\stackrel{10}{+i}$ & $\begin{array}{l}10 \\
\infty\end{array}$ & เి & $\stackrel{\circ}{+}$ & Lִ & $\stackrel{0}{0}$ & ف․ & L̊ & 20 & فه \\
\hline 念 & $\stackrel{100}{60}$ & $\stackrel{100}{0}$ & $\stackrel{\circ}{0}$ & $\stackrel{\text { Pִ }}{10}$ & $\stackrel{\circ}{\text { i }}$ & $\stackrel{20}{+10}$ & $\stackrel{\leftrightarrow \rho \rho}{\infty}$ & $\stackrel{\leftrightarrow}{\text { ì }}$ & 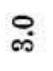 & مُ & فهم: & $\stackrel{\circ}{\circ}$ & $\stackrel{\circ}{\circ}$ & $\stackrel{0}{0}$ & فُ \\
\hline$\stackrel{B}{>}$ & : & $\stackrel{0}{0}$ & : & فำ & $\stackrel{10}{20}$ & $\stackrel{\circ}{i}$ & $\stackrel{\mathscr{L}}{\infty}$ & $\stackrel{\mathscr{N}}{\text { s. }}$ & 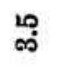 & $\stackrel{\circ}{\circ}$ & 이 & مُ & مٌ & ○ & $\stackrel{0}{0}$ \\
\hline 5 & 웅 & เด & $\stackrel{20}{\circ}$ & i̊ & is & $\stackrel{\circ}{\rightarrow}$ & $\stackrel{\infty}{\infty}$ & ஸे & $\stackrel{\circ}{\rightarrow}$ & 내요 & id & $\stackrel{0}{0}$ & 贺 & $\stackrel{\circ}{\circ}$ & مُ \\
\hline$>$ & 오. & 울 & $\begin{array}{l}10 \\
100\end{array}$ & id & เి & $\stackrel{10}{7}$ & $\stackrel{\circ}{+}$ & $\stackrel{\infty}{\infty}$ & $\stackrel{20}{+}$ & $\stackrel{0}{0}$ & 年 & $\stackrel{0}{0}$ & 울. & مִ & 20 \\
\hline Z & $\stackrel{\circ}{+}$ & $\stackrel{10}{+\infty}$ & 울 & $\begin{array}{l}10 \\
10\end{array}$ & $\begin{array}{l}200 \\
100\end{array}$ & 암 & $\stackrel{10}{+}$ & $\stackrel{L}{+0}$ & 울. & Lִ & LP & id & $\stackrel{20}{\rightarrow}$ & $\stackrel{0}{0}$ & : \\
\hline 寻 & $\stackrel{10}{+}$ & 约 & นึ. & $\stackrel{0}{0}$ & $\stackrel{0}{0}$ & $\stackrel{0}{0}$ & 量 & 送 & $\stackrel{0}{\circ}$ & $\stackrel{20}{6}$ & 노 & $\stackrel{\circ}{+}$ & 울 & هִ & ڤొ \\
\hline ヨ & 约 & & $\stackrel{0}{0}$ & $\stackrel{10}{6}$ & فِ & & فू & فी & $\stackrel{\circ}{\circ}$ & فु & & ஸे & فه 20 & $\stackrel{\circ}{\circ}$ & $\stackrel{\circ}{\circ}$ \\
\hline$H$ & ڤٌ & $\stackrel{\circ}{\circ}$ & $\stackrel{0}{0}$ & $\stackrel{20}{\circ}$ & $\stackrel{0}{\circ}$ & $\stackrel{100}{0}$ & فٌ & & $\stackrel{0}{0}$ & மூ & مُ & $\stackrel{\circ}{+}$ & فำ & ڤొ & மூ \\
\hline & 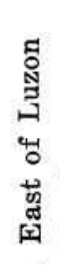 & 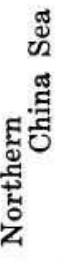 & 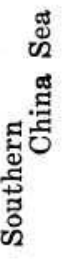 & 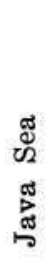 & 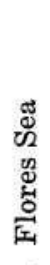 & 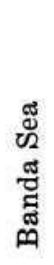 & 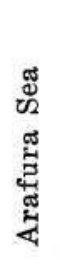 & 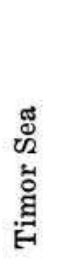 & 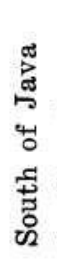 & 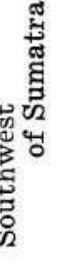 & 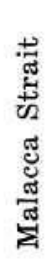 & 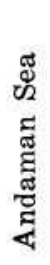 & 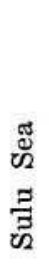 & 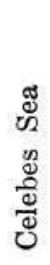 & 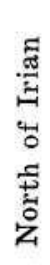 \\
\hline & -i & & க் & $\dot{\nabla}$ & 10 & 0 & $\check{\leftarrow}$ & $\infty$ & $\sigma^{\circ}$ & & $\ddot{ت}$ & ง & 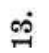 & $\underset{ت}{ }$ & 10 \\
\hline
\end{tabular}




\begin{tabular}{|c|c|c|c|c|c|c|c|c|c|c|c|}
\hline & & & & & & & & $\stackrel{8}{\circ}$ & & & 88 \\
\hline & & & ऽ & & 16 & $\xi$ & 品 & $\underset{\substack{\infty \\
\infty}}{\infty}$ & 䓵 & & \\
\hline & & & 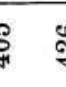 & & 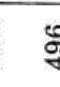 & $\xi$ & 总 & 酋 & 㣌 & & 啹 \\
\hline & & & 9 & & 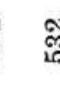 & 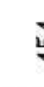 & ్ㅗㅀ & Б్ & 品 & & 至 范 \\
\hline & & & 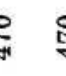 & & t: & $\xi$ & 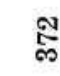 & \& & œ & ఐ & ‡ \\
\hline & & & 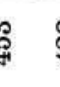 & & 5 & $\dot{s}$ & 品 & I & 器 & & $\infty_{\substack{\infty \\
\circ}}^{\circ}$ \\
\hline & & & $:$ & & ఫे & 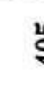 & 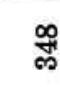 & 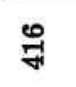 & $\begin{array}{c}\infty \\
\infty \\
\infty\end{array}$ & & : \\
\hline & & & 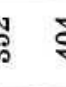 & & & $\vdots$ & ஜ & F & \% & & 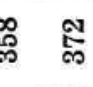 \\
\hline & & & 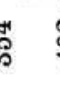 & & & 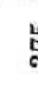 & 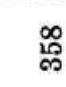 & $\stackrel{8}{8}$ & 际 & & S \\
\hline & & & $\vec{b}$ & & & $\S$ & ఖ్ల & ఫ్ & ஜ & & 啹 \\
\hline & & 5 & bُ & & ร & $\vdots$ & ఇ & 与్ & 윰 & tï & 沉 \\
\hline & & & 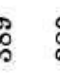 & & & $\vdots$ & 吅 & 骂 & 荅 & & 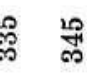 \\
\hline & & & 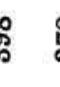 & & $\vdots$ & $\vdots$ & $\bar{m}$ & 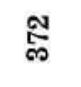 & F & 8 & 象 \\
\hline & & 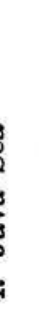 & 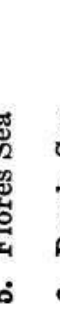 & & & & 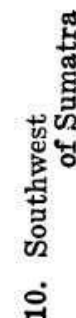 & 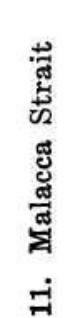 & 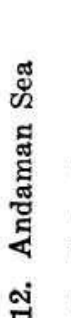 & & \\
\hline
\end{tabular}




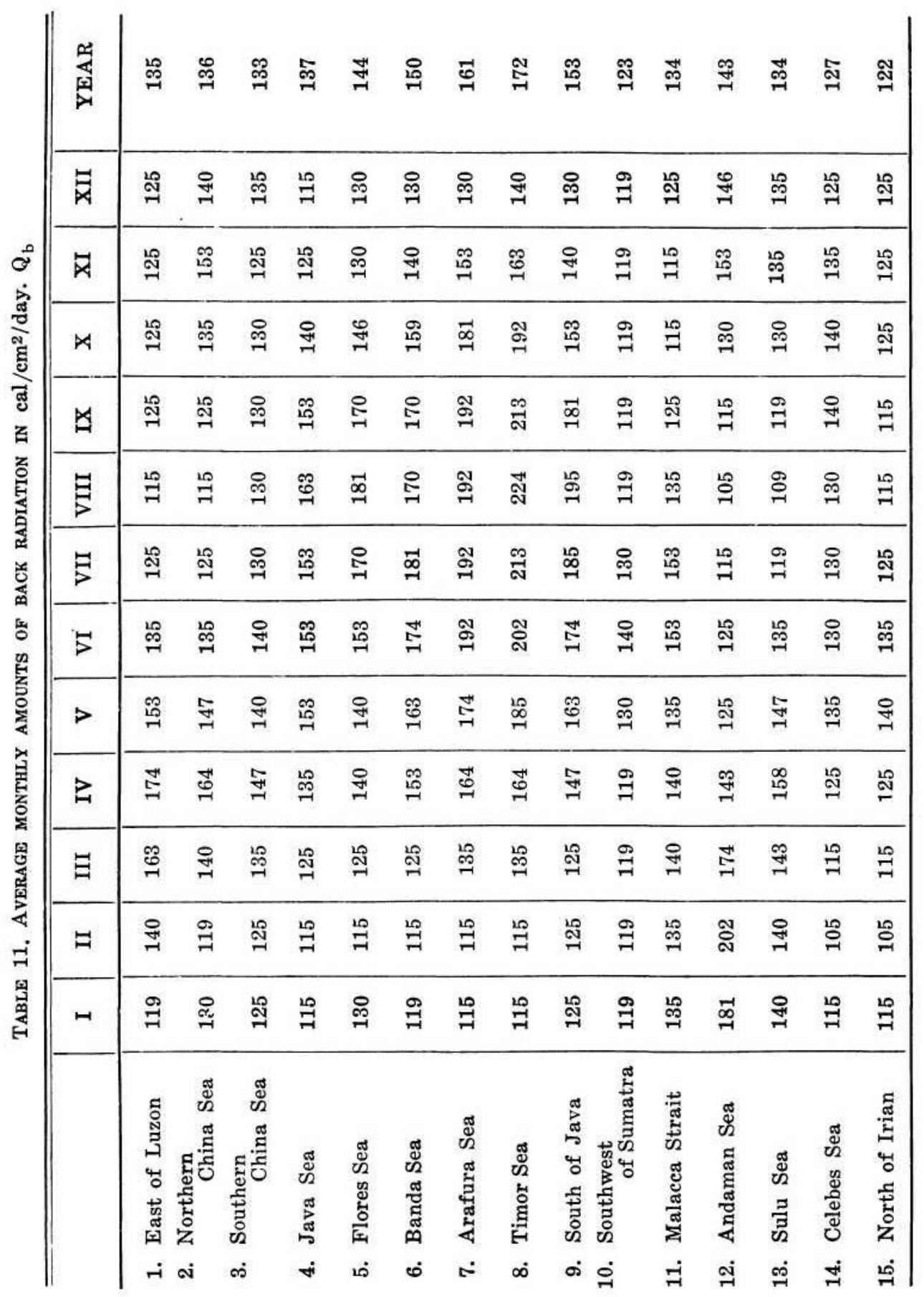




\begin{tabular}{|c|c|c|c|c|c|c|c|c|c|c|c|c|c|c|c|}
\hline 番 & 毘 & & & 怘 & เั & 芯 & ฟั & & & Iㄱ & & 兽 & ఫ్ & & 志 \\
\hline 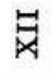 & 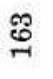 & $\stackrel{\infty}{\stackrel{\infty}{\rightarrow}}$ & ฐึ & 䒽 & 오ํ & 芯 & 跑 & 总 & $\stackrel{\varpi}{\infty}$ & 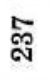 & ณึ & $\underset{\sim}{\mathbb{\sim}}$ & ๕̊ & $\stackrel{\infty}{\text { హ్ }}$ & đI \\
\hline$\vec{x}$ & E & $\underset{\sim}{\infty}$ & 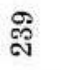 & 点 & ำ ำ & $\stackrel{\mathscr{D}}{\sim}$ & $\stackrel{\circ}{\circ}$ & œొ & 용 & ๙ึ & ณึ & สี & 㤐 & 旋 & 点 \\
\hline$x$ & క్ & 墕 & ֻั & ఊ̊ & $\underset{\circledast}{\circledR}$ & $\underset{\sim}{\mathscr{\omega}}$ & ळ్ & : ఝ్ల & ప్రి & 哭 & 品 & Iึ & 䓵 & $\overrightarrow{\stackrel{\infty}{~}}$ & $\stackrel{\circ}{\circ}$ \\
\hline$\not \Delta$ & 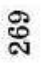 & : & 怘 & 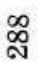 & ి. & ఃे & ๙్ల & ఖ્ఝ & 。̊ & ณ̊ & ำ 옹 & $\stackrel{\leftrightarrow}{\%}$ & క్ష & $\underset{\varpi}{\mathbb{\sim}}$ & 点 \\
\hline$\stackrel{\Xi}{5}$ & ֻొ & 恕 & 渋 & ָั & ฐิ & 怘 & స్ & \&్ఠ & $\varpi_{\infty}$ & ผ & 怘 & เి & 코 & $\stackrel{\infty}{\stackrel{\infty}{\leftrightarrow}}$ & 水 \\
\hline$E$ & ః & : & 芯 & $\stackrel{\infty}{\text { స్ }}$ & $\stackrel{\infty}{\text { สె }}$ & สึ & สิ & สิ & ๙ิ & $\stackrel{\infty}{\text { ส }}$ & ஜֶ: & : & ঙ্ন & 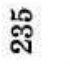 & $\stackrel{\infty}{\infty}$ \\
\hline 5 & ฌొ & ळ్ల & 茳 & สี & $\stackrel{\overbrace{}}{\circ}$ & 令 & ลั & ఃั & $\stackrel{\curvearrowleft}{\stackrel{్}{్}}$ & జి & 瓷 & $\underset{\leftrightarrow}{\infty}$ & $\underset{\mathrm{N}}{\mathbb{N}}$ & స్ & $\stackrel{s}{\infty}$ \\
\hline$>$ & న్ల్ & ஜ & ஜू ఝ & $\overrightarrow{\widetilde{\circledast}}$ & สี & ๙ొ & $\dddot{\varpi}$ & ลั & สี & స్ & 芯 & : & క్రి & 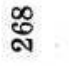 & $\mathbb{J}$ \\
\hline$z$ & 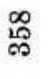 & $\stackrel{\infty}{\infty}$ & 芯 & $\overrightarrow{\mathrm{\sigma}}$ & 蛋 & ఊ్ & త్ర & เัติ & I্] & 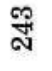 & 离 & ભ్లి & ణ్ల్ & 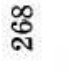 & 点 \\
\hline$\Xi$ & 品 & $\underset{\text { న్ }}{0}$ & 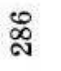 & $\stackrel{\infty}{\infty}$ & $\stackrel{\infty}{\infty}$ & $\stackrel{\infty}{\circ}$ & $\stackrel{\infty}{\sim}$ & $\stackrel{\mathscr{D}}{\infty}$ & $\stackrel{\infty}{\stackrel{\leftrightarrow}{*}}$ & 岕 & 䒽 & $\stackrel{\varpi}{๓}$ & $\vec{\varnothing}$ & 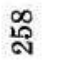 & $\begin{array}{l}\infty \\
\stackrel{\infty}{\sim}\end{array}$ \\
\hline$\exists$ & ฌู & ثั่ & 岕 & $\underset{\mathrm{N}}{\mathbb{N}}$ & 胥 & $\underset{\mathrm{N}}{\mathbb{2}}$ & ฌ્ & $\stackrel{100}{\infty}$ & న్ & 落 & 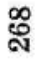 & ळू & 週 & ๙̊ & 엄 \\
\hline - & 营 & 总 & ฟิ & 离 & 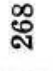 & 嵒 & $\stackrel{\infty}{\infty}$ & 疍 & నี & జ్ & 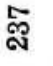 & สి & สิ & జิ & $\overrightarrow{\mathscr{N}}$ \\
\hline & 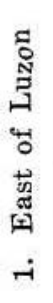 & 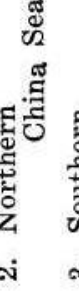 & 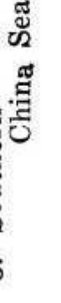 & 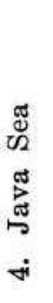 & 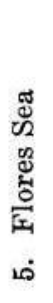 & 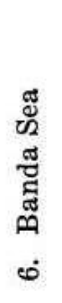 & 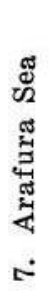 & 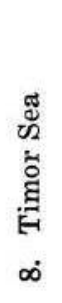 & 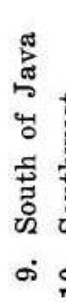 & 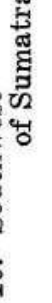 & 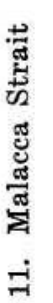 & 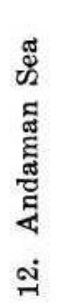 & 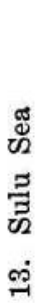 & 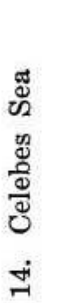 & 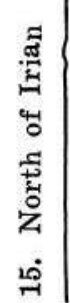 \\
\hline
\end{tabular}




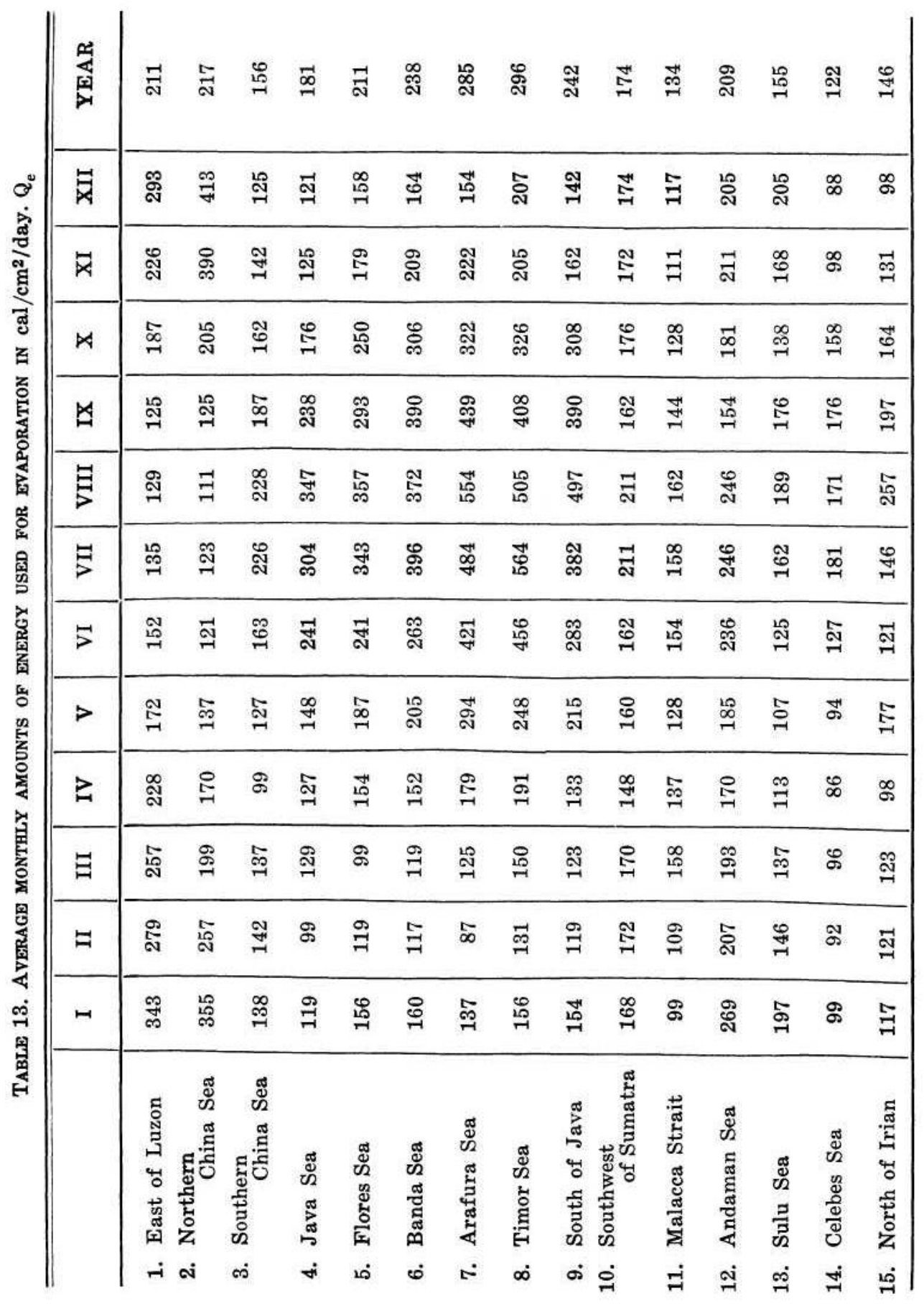




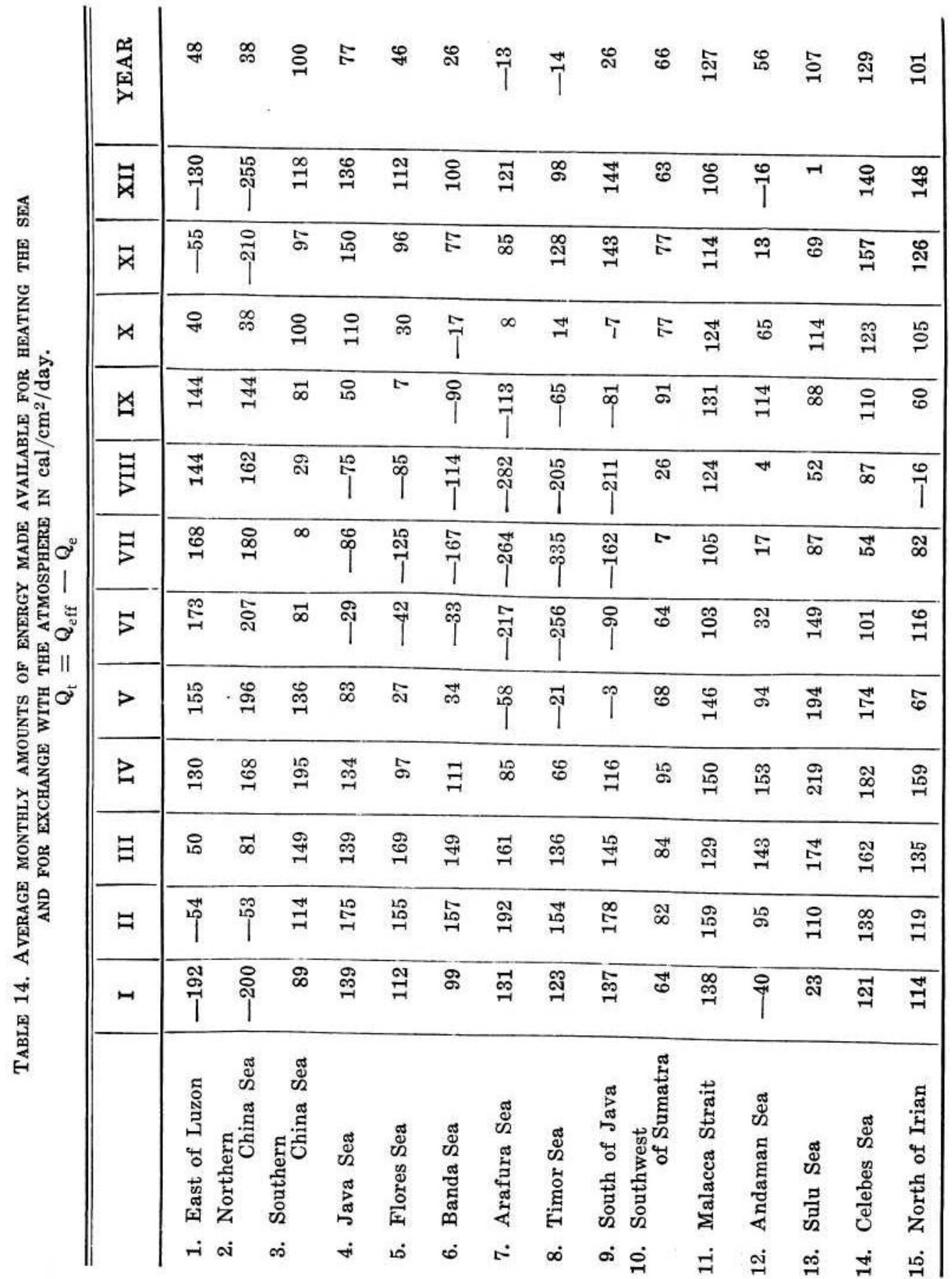

